\title{
The Road Less Traveled: Strategy Distinctiveness and Hedge Fund Performance
}

\author{
Zheng Sun
}

Ashley Wang

Lu Zheng

September 2009

We thank seminar and conference participants and discussants at the Cheung Kong 2009 Summer Finance Conference, the Financial Intermediation Research Society Conference 2009, the Singapore International Conference on Finance 2009, the UCLA/USC/UCI 2008 joint Conference, Arizona State University, California State University at Fullerton, George Washington University, Georgetown University, Santa Clara University, UCI Paul Merage School, University of Maryland, and University of Oregon. All errors remain ours. The authors are at the Paul Merage School of Business, University of California Irvine, CA 92697-3125. Sun is at (949) 824-6907, Email: zsun@merage.uci.edu; Wang is at (949) 824-9149, Email: ashwang@uci.edu; and Zheng is at (949) 824-8365; Email: luzheng@uci.edu. 


\title{
The Road Less Traveled: Strategy Distinctiveness and Hedge Fund Performance
}

\begin{abstract}
Presumably, hedge fund managers pursue unique strategies, because they possess innovative ideas and superior investment skills, while less skilled managers are more likely to herd and follow publicly known investment strategies. For investors, knowing how innovative and skillful their managers are is thus extremely important but difficult because of the opaque nature of hedge fund operations. In this paper, we construct a measure of the distinctiveness of a fund's investment strategy based on historical fund return data. Specifically, we examine the extent to which a fund's returns differ from those of its peer funds. We term the measure the "Strategy Distinctiveness Index" $(S D I)$. The higher the SDI, the more distinctive is a fund's strategy. We document a substantial cross-sectional variation, as well as strong persistence over time in funds' SDI. Our main result indicates that, on average, a higher SDI is associated with better subsequent performance. Funds in the highest SDI quintile significantly outperform funds in the lowest $S D I$ quintile by about $4 \%$ over the subsequent year after risk adjustment.
\end{abstract}




\section{Introduction}

Investors willingly pay high fees to hedge fund managers for their unique investment ideas and strategies in order to earn a high rate of return. When an investment idea becomes widely known, the abnormal return from the strategy is likely to be competed away. This, together with the welldocumented finding of large performance variations across hedge funds, suggests that identifying those fund managers possessed of unique investment ideas is crucial for hedge fund investors. However, the task is very challenging. First, hedge fund managers conduct their trading operations amid great secrecy, offering little disclosure in order to protect their investment ideas. Second, the rapid growth of the hedge fund industry has resulted in a wide range of strategies and a huge number of funds run by managers with diverse investment backgrounds and qualifications. In this paper, we make an initial attempt to estimate the uniqueness and distinctiveness of a fund's investment strategy using historical hedge fund return data. Further, we examine whether a distinctive investment strategy is indicative of greater managerial talents, and hence, superior fund performance.

Presumably, skilled hedge fund managers pursue distinctive strategies because they have great new ideas and superior investment skills, while less skilled managers are more likely to herd and follow publicly known investment ideas. We refer to this as the skill hypothesis. Consistent with this hypothesis, we would expect funds with skilled managers to pursue more innovative strategies and to deliver distinctive performance. As a result, we should observe a positive relation between distinctiveness in fund strategy and fund performance.

On the other hand, hedge fund managers may also appear to deviate from their peers by assuming excessive risk, due to a potential conflict of interest between fund managers and investors. As Goetzmann, Ingersoll, and Ross (2003) show, the option-like characteristics of the compensation 
contract can provide incentives for managers to make idiosyncratic bets to increase the chance of extreme performance. We refer to this as the gaming hypothesis. Consistent with this hypothesis, funds pursuing such gaming strategy would appear to be distinctive from their peers. However, in this case, we should not observe a positive relation between future fund performance and distinctiveness in fund strategy.

To study the distinctiveness of a fund's investment strategy, we propose a measure based on historical fund returns. Specifically, we examine the correlation of individual hedge fund returns with the average returns of peer funds in the same style category. In this context, we term (1 correlation) the "Strategy Distinctiveness Index" (SDI). The SDI measures the extent to which a fund's returns differ from those of its peers. The higher the SDI, the more distinctive is the fund's investment strategy. We then examine how SDI relates to fund performance and other fund characteristics.

We define fund investment styles by clustering historic returns using a procedure similar to that in Brown and Goetzmann $(1997,2003)$. The clustering method groups funds to its closest cohort by minimizing the sum of the distance of all funds to the corresponding clusters. The partition of funds is based on a systematic and quantitative approach rather than predefined categories. As suggested by Brown and Goetzmann (1997, 2003), the statistical approach precludes possible misclassification of fund styles, due to strategic self-reporting. The clustering method also allows for time-varying grouping, as some funds may change investment strategies over time. Moreover, we repeat the analysis using the predefined TASS styles as a robustness test.

Using monthly return data on about 3,600 hedge funds covered by the Lipper TASS database over the period of January 1994 to December 2008, we construct the SDI for individual funds. For the sample of funds, we control for survivorship and backfill biases to the extent the data 
allow. We document a substantial cross-sectional variation in the SDI, indicating that some funds follow innovative investment strategies, while others tend to herd. We also find strong persistence in individual fund SDI over time. This suggests that the SDI is likely driven by fund characteristics, such as managerial innovation skills, that tend to persist over time, rather than by noise or by random bets prompted by a manager's gaming motive that are likely to be transitory.

We further study the determinants of the SDI. We find that it is related to a number of fund characteristics. Specifically, the SDI increases with lagged performance measures including riskadjusted returns, appraisal ratio (AR), and the Sharpe ratio (SR). This result is consistent with the skill hypothesis that the SDI is related to better fund performance. Moreover, the SDI decreases with the lagged idiosyncratic volatility of fund returns. This result is inconsistent with the gaming hypothesis that the deviation captured by the $S D I$ is driven by managers making random bets and taking on excessive risk to maximize the option-like payoff. Furthermore, we find that the SDI decreases with fund age, size, length of lockup period, and high water mark provision dummy, and increases with redemption notice period, fund incentive fees, past flows, minimum investment, and leverage usage dummy.

Our main test concerns the relation between the SDI and fund performance. We form portfolios of hedge funds based on their SDI levels and examine the subsequent performance of these portfolios. Consistent with the skill hypothesis, we find that the SDI helps predict future fund performance. Funds with more distinctive strategies tend to perform consistently better after adjusting for differences in their risks and styles. Specifically, when we sort funds into portfolios based on the SDI every quarter and hold them for a year, the equally weighted quintile portfolio of funds with the highest lagged SDI yields an average risk-adjusted return of $7.95 \%$ per year, whereas that with the lowest SDI yields $4.00 \%$ per year. The return difference between the two portfolios is statistically and economically significant. 
Since the post-formation portfolio performance can only be measured based on funds that are present in the data set until the end of the holding horizon, the performance based on these existing funds may be biased. To examine whether the out-performance of the high SDI portfolio we have documented is mainly attributed to the difference in the dropout rate, we analyze the dropout property of the SDI portfolios. We find a $4 \%$ difference in the survival rate between the lowest and highest SDI quintile portfolios ( $84 \%$ and $80 \%$, respectively) 1 year after the formation. We show via back-of-envelope calculations that the differences in the dropout rate and the potential return bias are unlikely to explain away the out-performance of the high SDI portfolio.

We further examine the robustness of the above relation using a multivariate regression approach. Specifically, we use both pooled regressions with clustered standard errors and time- and stylefixed effects, as well as Fama-MacBeth regressions with heteroscedasticity and autocorrelation adjusted (HAC) standard errors. Controlling for other fund characteristics, we confirm the positive relation between a fund's SDI and its subsequent performance in the multivariate regression setting.

We also investigate whether our results hold up to alternative specifications for strategy distinctiveness. First, to ensure that our results are not specific to the cluster classification, we consider (1 - correlation) using the TASS styles, termed SDI(TASS). Then, we consider the (1 $\mathrm{R}^{2}$ ) of a regression of individual hedge fund returns against the average returns of all peer funds: $\left(1-R^{2}\right)$ captures the percentage of total variance in fund returns that cannot be explained by the returns of the average peer funds. The overall pattern in these results again confirms that the more distinctive the strategy, the better the future performance. 
The remainder of the paper is organized as follows. Section II discusses the related literature. Section III introduces the data. Section IV describes the construction of SDI, its properties, and its determinants. Section V presents the empirical findings on the relation between the SDI and future fund performance measures and robustness analysis. Section VI concludes.

\section{Related Literature}

Academic research shows that hedge funds follow dynamic investment strategies and have volatile returns. The empirical findings also indicate, in general, that hedge funds deliver positive alpha, while the evidence on performance persistence has been rather mixed ${ }^{1}$. Although hedge funds, as a group, deliver positive risk-adjusted returns and diversification benefits, large crosssectional variations in hedge fund returns have also been documented (see, for example, Malkiel and Saha, 2005).

Despite the importance of distinguishing skilled hedge fund managers from the unskillful ones, research on the cross-sectional determinants of hedge fund returns has been rather limited until a few recent papers started linking hedge fund performance to various fund and managerial attributes. Aragon (2007) and Liang and Park (2008) finds that funds with more stringent share restriction clauses offer higher returns. Aggarwal and Jorion (2009) document strong outperformance by emerging hedge fund managers, especially during the first 2-3 years of fund existence. Agarwal, Daniel, and Naik (2007) show that funds offering greater managerial incentives and discretion display superior performance. Li, Zhang, and Zhao (2007) find that

\footnotetext{
${ }^{1}$ See Ackermann, McEnally, and Ravenscraft (1999) Agarwal and Naik (2000 and 2004), Brown, Goetzmann, and Ibbotson (1999), Brown and Goetzmann (2003), Brown, Goetzmann, Liang, and Schwarz (2007), Fung and Hsieh (1997, 2000, 2001, 2002), Goetzmann, Ingersoll, and Ross (2003), Ibbotson and Chen (2006), Jagannathan, Malakhov, and Novikov (2006), Kosowski, Naik, and Teo (2007) and Liang (1999, 2000). Griffin and Xu (2007) analyze hedge fund disclosed holdings and find only weak statistical evidence for a better stock picking ability when comparing hedge funds with mutual funds.
} 
educational background and working experience of managers are related to hedge fund performance. Titman and Tiu (2008) find that funds run by managers with superior hedging skills exhibit lower $R$-squares with respect to systematic risk factors and subsequently outperform. Related to this line of research, our paper makes an initial attempt to study the innovation aspect of managerial talents and the distinctive quality of fund strategies.

The existing literature examining the effect of the innovativeness of managerial talents and distinctiveness of fund strategy on fund performance has been primarily focused on the mutual fund sector. Kacperczyk, Sialm, and Zheng (2005) argue that mutual fund managers may decide to deviate from a well-diversified portfolio and concentrate their holdings in industries in which they have informational advantages. Their results confirm that more concentrated funds perform better, after controlling for risk and style differences. In a related paper, Cremers and Petajisto (2007) propose a measure of Active Share for individual mutual funds to capture the share of portfolio holdings that differ from the benchmark index. They find that funds with the highest Active Share values significantly outperform their benchmark, both before and after expenses. Our paper, on the other hand, focuses on the universe of hedge funds and investigates whether innovative and distinctive strategies of hedge funds predict superior future performance.

Our paper is also related to a burgeoning line of research that aims to gauge the unobserved fund managers’ talents using publicly available fund return and holding data. Cohen, Coval, and Pástor Pastor (2005) propose to judge a fund manager's skill by how similar her portfolio holdings are to those of managers with superior performance records. They demonstrate empirically that their measures are useful in forecasting manager performance. Kacperczyk, Sialm, and Zheng (2007) propose a return gap measure to capture the unobserved actions taken by mutual fund managers. The return gap is defined as the difference between the reported fund returns and the return of a portfolio that invests in the previously disclosed holding adjusted for expenses. They find that the 
return gap, as a proxy for unobserved managerial talents, indeed helps predict future fund performance. Kacperczyk and Seru (2007) argue that a skilled manager tends to rely less on public information. They construct a Reliance on Public Information (RPI) measure to capture the responsiveness of a mutual fund manager's portfolio allocations to changes in public information, and they find a strong inverse relation between RPI and future fund performance. In this paper, we try to estimate the innovativeness of a fund's strategy, a previously unstudied aspect of disclosed fund performance, by analyzing fund historical returns.

\section{Data and Performance Measures}

The hedge fund data are from the Lipper TASS database, recognized as one of the leading sources of hedge fund information. The main data include monthly hedge fund returns, as well as fund characteristics. We start with a total of 12,784 funds, including live and graveyard funds. Then, following Aragon (2007), we filter out non-monthly filing funds and funds denoted in a currency other than US dollars, leaving 8,320 unique funds. To control for backfill bias, we further throw out the first 18 months of returns for each fund, yielding 7,250 unique funds. ${ }^{2}$ We then filter out fund of funds (FoFs), reducing our sample to 5,595 funds. ${ }^{3}$ We also filter out observations before 1994 and after 2008, leaving 5,501 unique funds. To reduce the noise in the fund distinctiveness measures, we exclude funds with fewer than 12 monthly returns within each preceding 24-month period, leading to a sample of 4,602 unique funds. Moreover, we filter out

\footnotetext{
${ }^{2}$ We also consider an alternative approach to controlling for backfill bias by removing returns before a fund joins the TASS database, following Aggarwal and Jorion (2009). The resulting sample size and overall pattern of the main findings remain qualitatively similar.

${ }^{3}$ Our SDI measure may not work well to predict future performance for FoFs. First, overlapped holdings of the underlying hedge funds may reduce the spread in the SDI across FoFs, which is confirmed in our unreported analysis, available upon request. Furthermore, superior FoFs may invest in similar underlying hedge funds; therefore, there is a counteracting effect against finding a positive link between the SDI and FoFs performance. We thank an anonymous referee for this insight. In an unreported analysis, we find no significant association between the SDI and FoFs performance. The results are available upon request.
} 
funds with assets under management (AUM) of less than 5 million dollars, giving us 3,630 remaining funds. Finally, for our regression analysis, we filter out funds with missing characteristics and extreme observations. This leaves a final sample of 3,539 funds.

TASS groups these hedge funds into 10 self-reported style categories, including convertible arbitrage, dedicated short bias, emerging markets, equity market neutral, event driven, fixed income arbitrage, global macro, long/short equity hedge, managed futures, and multi strategies. One-third of our sample funds is in the long/short equity hedge category. There are fewer than 30 funds in the dedicated short bias category. The rest of the sample is relatively evenly distributed across the remaining eight hedge fund categories.

The abnormal performance of a hedge fund is measured relative to certain benchmarks. Given the wide use of derivatives and dynamic trading strategies among hedge funds, the standard CAPM model cannot adequately capture the risk-return tradeoff for hedge funds. Therefore, we consider a few alternative choices as performance benchmarks. For our main results, we use the Fung and Hsieh (FH) 7-factor model (Fung and Hsieh, 2001) ${ }^{4}$ that includes an equity market factor, a size spread factor, a bond market factor, a credit spread factor, and trend-following factors for bond, currency, and commodities.

In addition, we use a modified appraisal ratio of Treynor and Black (1973), calculated by dividing the mean of the monthly abnormal returns by their standard deviation. Brown, Goetzmann, and Ross (1995) show that survivorship bias is positively related to fund return variance. Thus, the higher the return volatility, the greater the difference between the ex-post observed mean and the ex-ante expected return. Using the alpha scaled by the idiosyncratic risk as our performance measure mitigates such survivorship problems. Agarwal and Naik (2000) further point out that

\footnotetext{
${ }^{4}$ http://faculty.fuqua.duke.edu/ dah7/DataLibrary/TF-FAC.xls
} 
this measure is particularly relevant for hedge funds, given that it accounts for differences in leverage across funds.

Moreover, we employ the monthly Sharpe ratio to capture the risk-return tradeoff of hedge fund performance. It is defined as the ratio between the average monthly net fee returns in excess of the risk-free rate and the volatility in the monthly excess returns. We also consider the smoothingadjusted Sharpe ratio to control for illiquidity and smoothing in hedge fund returns, following Getmansky, Lo, and Makarov (2004) ${ }^{5}$. Details of the adjustment are provided in Appendix A.

\section{Hedge Fund SDI}

This paper investigates whether a distinctive investment strategy reflects innovative and skillful managerial talents, and is thus capable of predicting superior future performance. To measure the distinctiveness of a fund's investment strategy, we compare its historical returns with the average returns of its peers.

\section{A. Quantifying Hedge Fund Strategy Distinctiveness}

If a manager is skillful, she is likely to engage in an innovative and unique trading strategy, thereby delivering performance that co-moves less with the overall performance of the hedge fund sector, or the performance of the specific style to which her fund belongs. This suggests an intuitive measure to capture the distinctiveness of a fund strategy: one minus the sample correlation of a fund's return $\left(r_{i t}\right)$ with the average return of all funds belonging to the same style $\left(\mu_{I t}\right)$

\footnotetext{
${ }^{5}$ We thank an anonymous referee for this suggestion.
} 


$$
\begin{aligned}
S D I_{i} & =1-\operatorname{corr}\left(r_{i}, \mu_{I}\right) \\
& =1-\frac{\sum_{t=1}^{24}\left(r_{i t}-\bar{r}_{i}\right)\left(\mu_{I t}-\bar{\mu}_{I}\right)}{\sqrt{\sum_{t=1}^{24}\left(r_{i t}-\bar{r}_{i}\right)^{2} \sum_{t=1}^{24}\left(\mu_{I t}-\bar{\mu}_{I}\right)^{2}}}
\end{aligned}
$$

where $\mu_{I t}=\frac{\sum_{j \in I} r_{j t}}{\operatorname{count}(j \in I)}$. The SDI ranges between 0 and 2 in theory. Graphically, SDI can be viewed as a "distance" measure: the higher the $S D I$, the farther a fund is from its cluster and the more distinctive must be the fund's strategy.

To gauge how distinctive a fund's strategy is from its cohort, we first need to define hedge fund styles appropriately. Although TASS offers a classification scheme of 10 styles based on survey and voluntary reporting of hedge fund managers, this classification has a number of limitations.

First, the TASS style classification is based on voluntary self-reporting. This process may be error-ridden and possibly subject to managerial manipulation. Despite the lack of direct evidence, we have designed a test that sheds light on this issue. The premise of our test is that if the TASS classification is accurate, we would expect returns of a fund to have the highest $\mathrm{R}^{2}$ (or correlation) with the self-reported TASS style index returns. For each hedge fund, we estimate the $\mathrm{R}^{2}$ (or correlation) of returns associated with each of the 10 TASS style indices using the whole time series. The index yielding the highest $\mathrm{R}^{2}$ (correlation) is identified as the "best fit index" for that fund. We then count the fraction of hedge funds whose "best fit index" coincides with its self-reported TASS style index. The more accurate the TASS style classification is, the higher the fraction is expected to be. Our results show that only $37 \%$ (40\%) of funds turn out to have the self-reported TASS style index as the "best fit index" based on $\mathrm{R}^{2}$ (correlation). This evidence substantiates our concern of misspecification in the self-reported TASS styles. 
Second, the TASS database only provides the most recent snapshot for fund style and characteristics. Therefore, we are unable to examine if, and to what extent, hedge funds' styles have changed over time. Ideally, if hedge fund holding and trading information were available, we could evaluate whether there is any style switching by hedge funds. Such information, however, is unavailable. Therefore, we have designed another test to examine the stability of the "best fit index" for each fund. Specifically, at each quarter for each fund, we use a rolling window of 24 months to estimate the $\mathrm{R}^{2}$ (correlation) of individual fund returns with each of the 10 TASS styles. We identify the "best fit index" for the fund that yields the highest $\mathrm{R}^{2}$ (correlation) at that quarter. If the "best fit index" for a fund changes over 2 consecutive quarters, we consider this to be a style switch. We count the fraction of time a fund undergoes style switching, then average across funds. We find that on average, 31\% (27\%) of the time, a fund switches its style over time. This evidence suggests that the latest snapshot of the TASS styles may not be the most accurate in capturing the true investment and trading style for individual funds over time.

Third, and perhaps most problematic, funds in broadly defined styles may appear more distinctive than those in other narrowly defined styles, not necessarily because of their distinctive strategy, but due to their being more widely dispersed within the broadly defined style. In this case, the difference in the SDI measure may reflect the style difference. In particular, we compare the distribution of the SDI for each style and find large variations across TASS styles. For example, the average $S D I$ for the dedicated short bias is 0.27 , while that for the equity market neutral is 0.82. This suggests a possible confounding style effect associated with the TASS style-based SDI measure.

To address these issues, this paper defines styles (i.e., cluster styles) by clustering historic returns. At the beginning of each quarter, for funds with more than 12 monthly returns over the preceding 24-month period, we group them into K clusters, that is, K styles, based on the correlation of fund 
returns. The clustering procedure is similar to the method in Brown and Goetzmann (1997, 2003). The goal of the procedure is to find a locally optimized partition among funds, so that it minimizes the sum of the distance of all funds to the corresponding clusters. This quantitative method, by design, groups each fund to its closest cohort and captures style-shifting by funds if it occurs. It also balances among all clusters so that the strategy distinctiveness measure is more comparable across clusters. For example, the lowest average $S D I$ for a cluster is 0.30 , while the highest for a cluster is 0.47 . The difference of 0.17 is much smaller than the spread between 0.82 , the average $S D I$ for the equity market neutral, and 0.27 , the average $S D I$ for dedicated short bias. Therefore, it is less likely that the cluster style-based SDI is subject to the confounding style effect compared with the TASS style-based SDI.

\section{B. Properties of the Cluster Styles}

To better understand the clustering results, first, we compare how much overlap exists between the statistically defined cluster styles and the self-reported TASS styles. In our study, we fix the number of clusters at 10 , the same as the number of the TASS styles. In Table B1 in the Appendix, we report the cross-tabulation of the cluster styles with the TASS styles. Since the self-reported styles are identified only at the end of the sample, we compare them with the endof-sample clusters estimated based on the last 2 years of return data ${ }^{6}$. As seen from Table B1, the cluster styles and the TASS styles do not perfectly match. Each of the relatively narrowly defined styles, such as “Convertible Arbitrage," "Dedicated Short Bias,” “Emerging Markets,” and "Managed Futures," tends to concentrate in one or two clusters, which, when combined, consist of more than $50 \%$ of funds in that style. This confirms that the clustering methodology indeed groups together funds with similar strategies. On the other hand, funds in broadly defined styles such as "Equity Market Neutral,” “Event Driven,” “Fixed-Income,” “Global Macro,” “Long-

\footnotetext{
${ }^{6}$ We also compare clusters defined based on the whole sample of returns with the TASS styles. The results are similar.
} 
Short Equity," and "Multi-Strategy” spread widely across clusters. This further indicates that the TASS style classification may lump together funds that are fundamentally different, thus making it problematic to construct the strategy distinctiveness measure based on the TASS styles.

Second, we examine the stability of the clustering results. Since we update the clusters over time, funds belonging to one cluster this quarter may not necessarily be grouped together in the next quarter. However, if two funds are grouped together because of some fundamental link, then the clustering should remain stable over time. We test this hypothesis by analyzing pair-wise connections between funds for each period, and the details are provided in Appendix B2. For each year, we count the fraction of change in the pair-wise connections between funds, considered the switching rate. We find an average annual switching rate of $16.2 \%^{7}$, comparable with 17.6\% found by Brown and Goetzmann (1997) based on a mutual fund sample. The low switching rate confirms the stable grouping by the clustering procedures. We also bootstrap the switching rate under the null hypothesis that funds are grouped into clusters by random chance. The average switching rate under the null is $29.7 \%$. Plotting the entire distribution of the null rate reveals that the sample switching rate for each year is below the 1 percentile of the bootstrapped distribution, suggesting that the clusters are significantly more stable than if they were grouped by random chance.

\section{Properties of the SDI}

In the following, we investigate the properties of the $S D I$, based on the cluster styles.

\footnotetext{
${ }^{7}$ As pointed out by Brown and Goetzmann (1997), this switching rate overrepresents the fraction of funds that change styles over time. A simple numerical example can illustrate the point: suppose there are four funds, with Funds 1 and 2 in Style A and Funds 3 and 4 in Style B at time 1. Assume Fund 1 shifts from Style A to Style B, and all other funds remain unchanged at time 2. Then the switching rate for this case is $50 \%$ (3 out of 6 pair-wise connections change from time 1 to time 2), while the corresponding style shifting rate is only 25\%, since only Fund 1 shifts styles.
} 


\section{C.1. Heterogeneity of the SDI}

There is a clear pattern of large variations in the distinctiveness of trading strategies across hedge funds. Panel A of Table 1 reports the time-series averages of the cross-sectional summary statistics of the main variables. The SDI has a mean (median) of $0.32(0.29)$, with a standard deviation of 0.18. The histogram presented in Figure 1A further confirms the heterogeneous pattern in the SDI. More than $80 \%$ of the sample funds exhibit an SDI lower than 0.50 . The distribution is more than $15 \%$ in each of the 0.15 to 0.35 SDI bins, and close to or more than $10 \%$ in both the 0.05 and 0.45 SDI bins. Funds scoring higher than 0.70 in SDI account for less than $5 \%$ of the total sample.

To see whether the clustering method better classifies funds than the self-reported TASS styles, we also compute the SDI based on the TASS styles. Specifically, we calculate one minus the sample correlation between each fund's returns with the average returns of all funds within the same TASS style. Figure 1B plots the histogram of SDI based on the TASS styles. As can be seen from the figure, the TASS style-based SDI is more right skewed compared with the cluster stylebased SDI. The mean is 0.52 , considerably higher than the average cluster style-based SDI of 0.32. Also note that there are $10 \%$ of funds with TASS style-based SDI greater than 1 , indicating that the funds' returns are actually negatively correlated with the average returns of the funds within the same TASS styles. Overall, these patterns confirm that the clustering methodology better identifies funds with similar strategies.

A comparison of the cluster style-based SDI measures between the live and graveyard funds shows a similar level of SDI: the means of $S D I$ for the live and graveyard funds are 0.31 and 0.33 , respectively. Moreover, the proportion of the live and graveyard funds remains at about a 40/60 split across the SDI bins, as evident in Figure 1A. These statistics suggest that findings on the 
relation between the SDI and fund performance are likely not driven by the different levels of SDI for live and graveyard funds.

In Figure 2, we examine the relative distribution of hedge funds across cluster styles in each of the SDI bins. The relative proportion of each cluster is stable across the bins. This finding suggests that the difference in the SDI measure is not driven by the difference in cluster styles, and hence, any performance difference associated with the SDI is also most likely not driven by the style difference.

To better understand how SDI varies across funds with different characteristics, we report the time-series average of the pair-wise correlations between the SDI and the contemporaneous fund characteristics. Panel B of Table 1 yields several noteworthy points. First of all, there is a positive correlation between the SDI and fund performance as measured by alpha, appraisal ratio, and Sharpe ratio. Second, there is a negative correlation between the SDI and fund return volatility (Vol). Finally, younger funds, funds with a longer redemption notice period, and funds with higher incentive fees tend to have a higher SDI in our sample.

\section{C.2 Persistence in the SDI}

If the deviation in hedge fund returns from its peers is driven by innovations in trading strategies and managerial skills, funds should display persistent SDI over time. For example, if a hedge fund exhibits high SDI in one period due to the manager's unique informational advantage or unique approach in processing information, its index level is likely to remain high in the future: managers are inclined toward their usual resources and styles, as long as the market capacity for this type of strategy has not been fully exhausted. 
To test this hypothesis formally, we sort all funds in our sample into quintile portfolios according to their lagged SDI measures and compute the average SDI for each quintile during the subsequent 3 months, 6 months, and 1-3 years. Note that the SDI measure is always constructed using a rolling 2-year window. Also note that there is no look-ahead bias, as we keep a fund whenever it exists if it does within 3 years. Table 2 reports the average index levels of the quintile portfolios, both at the sorting time and during the next 3 months to 3 years. The future index levels of the high SDI portfolios remain higher than those of the low SDI portfolios, for all five holding horizons we considered. The difference in the SDI between the high and low SDI portfolio decreases over time, but remains economically and statistically highly significant even after 3 years, at a level of 0.20 . These results suggest a strong persistence in the SDI measure.

\section{Determinants of the SDI}

To better understand what affects the level of distinctiveness of a hedge fund's performance, in this subsection, we examine the relation between the $S D I$ and lagged fund-specific characteristics. Specially, we use a multivariate panel regression approach based on annual data, controlling for fund clustering and time- and cluster style-fixed effects. The lagged fund characteristics considered include fund return volatility $(\mathrm{Vol})$, lengths of redemption notice and lockup periods, personal capital commitment dummy, high water mark dummy, management fees, incentive fees, fund age, natural logarithm of $A U M$, flow into funds, minimum investment, leverage dummy, average monthly net fee returns, FH7-factor alpha and the corresponding appraisal ratio, and the Sharpe ratio.

Table 3 summarizes the results. They are consistent with the overall patterns we observe from the correlation matrix in Panel B of Table 1. Specifically, the SDI increases with both the average net fee returns and the risk-adjusted performance measures, including the FH7 alpha, appraisal ratio, and Sharpe ratio, indicating a positive relation between SDI and fund performance. This finding is 
consistent with the skill effect. Moreover, the SDI decreases with Vol, length of lockup period, high water mark dummy, fund age, and fund size, while it increases with the length of redemption notice period, personal capital dummy, fund incentive fees, past fund flows, minimum investment, and use of leverage. The negative relation between the SDI and Vol suggests that our measure of fund performance deviation from its peers is most likely not driven by managers making random bets and taking on excessive risk to maximize the option-like payoff. Instead, the deviation measured by our SDI is likely associated with managerial talents in designing and implementing innovative strategies. The statistically significant association of the SDI with the redemption notice period and high water mark dummy makes economic sense. A longer redemption notice period gives managers a better cushion in which to implement their investment ideas, thereby allowing more room for innovation. High water mark clauses, on the other hand, may make managers more risk averse, and hence, more likely to herd. The results regarding fund age, size, usage of personal capital, and incentive fees are intuitive if the SDI reflects a talent for innovation. Managers of young funds are likely to pursue innovative ideas. Managers of small funds, being more nimble, can more readily incorporate innovations into their current practice. Commitment of personal capital and higher incentive fees may better motivate managers to pursue innovative and profitable strategies. This is also consistent with the belief that more talented managers may charge higher fees, or that they are more willing to invest their own money in such vehicles.

\section{The SDI and Fund Performance}

Until now, we have provided evidence that the SDI has appealing properties that are consistent with its potential of being an effective proxy for managerial innovation skills. In this section, we test the main hypothesis of the paper, that is, whether the SDI indeed contains valuable 
information that can be used to predict future fund performance. We probe this question using both a portfolio sorting and a multivariate predictive regression approach.

\section{A. Portfolio Sorting}

To gauge the relative performance of funds with different SDI levels, at the beginning of each quarter, we sort all hedge funds into five portfolios according to their SDI levels measured over a previous 24-month period. For each quintile portfolio, we compute the equally and value weighted average buy-and-hold performance for the subsequent quarter. We also consider the performance of these quintile portfolios held for the subsequent 6 months and 1-3 years.

We consider various performance measures for each quintile portfolio, including the average FH7-factor adjusted alphas, a modified appraisal ratio of Treynor and Black (1973), and the smoothing-adjusted Sharpe ratio. For each fund, we compute the monthly FH7-factor alpha using a rolling estimation of the prior 24 months. We then compound the monthly alpha to derive the 3month and up-to-3-year cumulative alpha for each fund, and then average across funds within each quintile to get the corresponding portfolio alphas. The appraisal ratio for each fund is calculated as the ratio between the mean of its monthly FH7-factor adjusted returns over the holding period and the standard deviation of the monthly alphas. The Sharpe ratio is calculated in a similar way using the monthly net fee returns in excess of the risk-free rate and adjusted for smoothing as detailed in Appendix A. We then take the average within each portfolio to derive the appraisal ratio and Sharpe ratio of the quintile portfolios. Table 4 summarizes the time-series average of these performance measures for each quintile portfolio, as well as the difference between the high and low SDI portfolios. The corresponding t-statistics are adjusted for heteroscedasticity and autocorrelation. 
For the equally weighted portfolios, the FH7-factor alphas increase almost monotonically with the past SDI measures for all five holding horizons. For a trading strategy of sorting every 3 months and holding for the subsequent year, funds in the highest SDI quintile, in which managers tend to follow distinctive investment strategies, earn an abnormal return of $7.95 \%$ per annum, with a $t$-statistic of 8.59 . Those in the lowest SDI quintile, in which managers tend to herd the most, on the other hand, yield a return of $4.00 \%$ each year, after controlling for the FH7-factor. The performance difference between the top and bottom quintiles is $3.95 \%$ per annum and statistically significant. For other holding horizons, funds in the highest SDI quintile consistently outperform those in the lowest quintile by about $2-4 \%$ per annum, after adjusting for the FH7factor. To earn these return spreads, one has to set up a trading strategy going long on funds with the most innovative investment skills, and short on those most likely to herd. The long side of this trading strategy alone can actually secure a better abnormal return of $6-8 \%$ per annum for all holding horizons.

As a fund deviates from its benchmark performance, it will be exposed to idiosyncratic risk. To take into account the different levels of unique risk across our sample of funds, we use a modified appraisal ratio of Treynor and Black (1973). For the equally weighted portfolios, there is a clear tendency for the appraisal ratio to increase with the SDI. The difference between the top and bottom SDI portfolios is 0.35 with a $t$-statistic of 4.11 for a holding horizon of 3 months. When the holding horizon is extended to a 1-year period, the difference in the appraisal ratio between the high and low SDI portfolios converges, but still remains highly significant at a level of 0.26 with a $t$-statistic of 5.57. The difference in the appraisal ratio shrinks to 0.20 and remains significant when the holding horizon is extended to 3 years.

To ensure that our portfolio sorting results are not specific to the FH7-factor performance benchmark, we also consider the smoothing-adjusted Sharpe ratio that is based on the monthly 
net fee returns in excess of a risk-free rate ${ }^{8}$. The equally weighted portfolio Sharpe ratio increases monotonically from the lowest SDI quintile to the highest one for all five holding horizons. For the 1-year holding horizon, the high SDI portfolio outperforms the low one by 0.12 , significant at the $1 \%$ level. In general, the spread in the smoothing-adjusted Sharpe ratio ranges from 0.07 to 0.22 across various holding horizons and is significant at the $1 \%$ level or better.

The value weighted portfolio sorting results are qualitatively similar, compared with the equally weighted ones. For example, based on a 1-year holding period, funds in the highest SDI quintile significantly outperform those in the lowest quintile by 3.19\% per annum, after controlling for the FH7-factors. In general, the magnitude of the spread in the annualized FH7-factor alpha between the value weighted extreme quintiles is smaller than that of the equally weighted portfolios, but still remains highly significant except in the case of the 3-month holding horizon. The results based on appraisal ratios and Sharpe ratios are essentially the same as the equally weighted ones, both in magnitude and statistical significance. Overall, these findings suggest that our results are not driven by small funds playing a dominant role.

\section{B. Multivariate Predictive Regression Analysis}

In this section, we further extend our analysis using a multivariate regression approach. The quintile portfolio analysis does not control for hedge fund characteristics that are known to affect future performance. For example, funds with more innovative investment strategies may be smaller than those likely to herd. Moreover, managers of innovative funds may be offered different incentive contracts from those of go-along-with-the-crowd managers. Our previous findings on a positive association between the SDI and future fund performance may be driven by size or other fund characteristics. A multivariate regression framework can help differentiate the alternative explanations by simultaneously controlling for these different factors.

\footnotetext{
${ }^{8}$ Results based on the raw Sharpe ratios yield similar findings and are available upon request.
} 
To investigate whether the SDI has a predictive power for future fund performance after controlling for other fund-specific characteristics, we estimate the following:

$$
\text { AbnormalPerformance }_{i, t}=c_{0 i}+c_{1 i} S_{D I} I_{i, t-1}+c_{2 i} \text { Control }_{i, t-1}+e_{i, t}(2)
$$

where AbnormalPerformance ${ }_{i, t}$ is the risk-adjusted fund performance within 1 year after the SDI is calculated. Specifically, we consider the compounded alpha, the corresponding appraisal ratio, and the smoothing-adjusted Sharpe ratio.

We use the lagged control variables to mitigate potential endogeneity problems. The Controls $_{i, t-1}$ consist of performance volatility measured by the volatility of prior 24-month fund returns in percent $(\mathrm{Vol})$, redemption notice period measured in a unit of 30 days, lockup months, indicator variables for whether personal capital is committed and whether there is a high water mark requirement, management fees, incentive fees, ages of funds in years, natural logarithm of $A U M$, flows into funds within the last year as a fraction of $A U M$ in percent, ${ }^{9}$ average monthly net fee returns in the preceding 24-month period, minimum investment, and a dummy variable for use of leverage or not. These variables are suggested by the existing literature on hedge fund characteristics and performance. If the distinctiveness index indeed reflects innovative and skillful managerial talents, we should expect its estimated coefficient to be significantly positive.

Our data are a pooled time series and cross-sectional unbalanced panel data. Given the stale price issue for hedge fund data documented by Getmansky, Lo, and Makarov (2004), the resulting alphas may be correlated over time for a specific fund; hence, we must correct for the fundclustering effect. Moreover, hedge fund performance may also be correlated across funds at a given point of time. Therefore, we need to correct for the time effect. As Petersen (2005) shows,

\footnotetext{
${ }^{9}$ To control for data errors, we excluded observations of flow higher than $1,000 \%$ or lower than $-1,000 \%$.
} 
clustering standard error is the preferred approach in addressing the fund effect, while FamaMacBeth is appropriate for correcting for the time effect. When both effects exist, we need to address one parametrically and then estimate standard errors clustered on the other dimension. We thus adopt two approaches. The first approach is the pooled panel regression adjusting for both fund-clustering and time- and style-fixed effects. The second approach is the Fama-MacBeth cross-sectional analysis with style dummies and the Newey-West heteroscedasticity and autocorrelation adjustment (HAC). Since there are only 12 years in our sample, the annual regression, especially for the Fama-MacBeth analysis, will be subject to the issue of limited statistical power. Therefore, our regressions use data of quarterly frequency.

\section{B.1 Panel Regression Analysis}

For the panel regression, we pooled the time series of all funds together to estimate Equation (2). The results are reported in Table 5, where the $t$-statistics are adjusted for fund-level clustering effect and time- and cluster style-fixed effects. Since risk-adjusted returns better reflect managerial talent, we focus on the regression results with the FH7-factor adjusted returns and the corresponding appraisal ratios, as well as the smoothing-adjusted Sharpe ratios, as the dependent variables. Table 5 demonstrates that the SDI has an important impact on future fund abnormal performance, even after controlling for other fund characteristics.

For the panel regression of alphas, the estimated coefficient for the $S D I$ is 4.81 with a $t$-statistic of 4.10, when time- and cluster style-fixed effects are controlled. This implies that a one-standarddeviation increase in the SDI predicts an increase in the annualized FH7-factor returns of $0.87 \%$ in the subsequent year, in the presence of a host of control variables. The signs of the coefficients for other fund characteristics are largely consistent with the existing literature. For example, the length of redemption notice period and lockup period is significantly and positively associated with future fund alpha. This corroborates the findings in Aragon (2007) and Liang and Park 
(2008) documenting that funds with more stringent share restriction clauses offer higher returns to compensate for illiquidity. High water mark dummy variable and management fees are significantly and positively related to future alpha. These results are similar to the findings in Agarwal, Daniel, and Naik (2007) arguing that hedge funds outperform when managers are better incentivized. $A U M$ is negatively associated with the future alpha, consistent with the notion of performance erosion due to increased scale in the mutual fund sector, as discussed in Berk and Green (2004) and Chen, Hong, Huang, and Kubik (2004). Finally, FH7-factor alpha increases with the minimum requirement for investment and the use of leverage.

The FH7-factors cover a large span of major asset classes, allowing the model to capture the riskreturn tradeoff for hedge funds with different strategies. Hence, we have chosen the FH7-factor model as the primary benchmark to gauge abnormal returns of hedge funds thus far. However, there are alternative performance benchmarks that contain relevant factors to capture the riskreturn tradeoff for hedge funds. Following Agarwal and Naik (2004), we consider as alternative performance benchmarks a model combining Carhart 4 factors and returns on the at-the-money and the out-of-the-money call and put options on the S\&P 500. The panel regression yields a similar effect of the SDI on the new alpha. For example, a one-standard-deviation increase in the SDI leads to an increase of $1.04 \%$ in the new alpha in the subsequent year.

We also adopt the appraisal ratio as an alternative performance measure. The results indicate a strong positive association of the SDI and future appraisal ratio. ${ }^{10}$ For example, a one-standarddeviation increase in the SDI will result in an increase in the FH7-factor appraisal ratios of 0.06

\footnotetext{
${ }^{10}$ We exclude lagged volatility from the regressor set for the appraisal ratio and the smoothing-adjusted Sharpe ratio. Since both ratios are already scaled by volatility of alphas or excess returns, further regressing these variables on another return volatility measure may cause a mechanical negative link between them. Nevertheless, our main results on the positive association between the SDI and performance measures remain the same, regardless of the regression specification.
} 
when time- and cluster style-fixed effects are controlled for. Finally, the effect of the SDI on the smoothing-djusted Sharpe ratio is also strongly positive and significant. A one-standard-deviation increase in the SDI leads to an increase of 0.02 for the smoothing-adjusted SR.

\section{B.2 Fama-MacBeth Analysis}

Using the Fama-MacBeth approach, for each quarter, we perform the cross-sectional regression of Equation (2) together with cluster-style dummies to obtain the estimated coefficients. Then, we use the time series of the estimated coefficients to derive the final Fama-MacBeth regression results with the Newey-West heteroscedasticity and autocorrelation adjustment on standard errors. The results are reported in Table 6. For the regression of the FH7-factor alphas, the estimated coefficient on the $S D I$ is 4.45 with a $t$-statistic of 2.92 , when cluster-style dummies are controlled for. Since the difference in the SDI between the high and low portfolios up to 1-year post-formation falls between 0.31 and 0.51 according to Table 2, the implied difference in the FH7-factor alpha between the extreme quintiles is about $0.31 \times 4.45=1.38 \%$ to $0.51 \times 4.45=2.27 \%$. Similarly, the difference in the FH7-factor appraisal ratio between the extreme quintiles is about $0.31 \times 0.35=0.11$ to $0.51 \times 0.35=0.18$. The implied difference in the smoothing-adjusted Sharpe raito between the extreme quintiles is $0.31 \times 0.14=0.04$ to $0.51 \times 0.14=0.07$. Overall, the results from the Fama-MacBeth analysis are consistent with those from the panel regression and the portfolio analysis. 


\section{Robustness}

In this section, we conduct robustness tests on our main findings. First, we investigate whether our results are robust to alternative specifications for strategy distinctiveness. Second, we examine whether our results hold up to a dropout bias, resulting from the fact that no performance records are available after funds stop reporting to the TASS database.

\section{C.1 Alternative SDI Measures}

Despite the caveats associated with the TASS style classification detailed in Section IV.A, to ensure that our main findings are not specific to the cluster-style classification, we conduct the portfolio sorting and multivariate regression analysis based on (1-correlation) using the TASS styles, termed SDI(TASS). Results reported in Table 7 corroborate our main findings. In particular, the difference in the annualized FH7-factor alpha between the equally weighted high and low TASS style-based SDI quintiles ranges from $3.51 \%$ to $1.58 \%$ for a 3-month to 3-year holding horizon; the difference in the FH7-factor based appraisal ratio ranges from 0.42 to 0.18 ; and the difference in the smoothing-adjusted Sharpe ratio ranges from 0.21 to 0.08 , for a 3-month to 3-year holding horizon. These findings are consistent with the results based on the cluster styles. Similar patterns are observed using the value-weighted portfolios. However, in the panel and Fama-MacBeth regression analysis, while SDI(TASS) continues to predict future alpha and appraisal ratio, its predictive power for the Sharpe ratio is not as robust as the cluster style-based SDI measure. The weakened result is likely due to the confounding style effect associated with SDI(TASS), which first prompted us to focus on a cluster style-based SDI.

We also investigate whether another intuitive measure for the distinctiveness of a fund strategy is associated with future outperformance. In particular, we consider the R-squared of a regression of individual hedge fund returns against the average returns of all peer funds: 


$$
r_{i, t}=c_{0 i}+c_{1 i} \text { Benchmark }_{t}+u_{i, t}
$$

$\left(1-R^{2}\right)$ captures the percentage of total variance in fund returns that cannot be explained by the returns of all peer funds. The higher the $\left(1-\mathrm{R}^{2}\right)$, the more distinctive is the fund's strategy. For simplicity, we use TASS style as the benchmark. We then relate the $1-\mathrm{R}^{2}$ (TASS) to the subsequent performance measures. The overall pattern in the results, reported in Table 7, again confirms that the more distinctive the strategy, the better the future performance.

\section{C.2 Control for Dropout Bias}

Although we include both live and graveyard funds in the portfolio analysis, there is no return data available after funds stop reporting and drop out of the data set. If the dropout funds continue to operate and the unreported performance of these funds is substantially different from the performance of existing funds, the observed portfolio return based on existing funds would be biased. We refer to this potential bias as the dropout bias. This bias raises the concern that the observed performance difference across the SDI quintiles might be due to the difference in the dropout rate, rather than true performance. Fund and Hsieh (2000) point out that the magnitude of the dropout bias should be a fraction of the normal survivorship bias. To further examine this issue, we analyze the dropout property of the SDI portfolios and gauge the impact of the potential bias on our findings via some back-of-the-envelope calculations.

Table 8 reports the survival rate for the SDI sorted portfolios corresponding to the ones reported in Table 2. In general, funds in the high SDI portfolios experience a higher dropout rate than funds in the low SDI portfolios. For example, about $84 \%$ of the funds in the lowest SDI quintile remain in the data set 1 year after portfolio formation, while $80 \%$ of the funds in the highest SDI quintile remain. 
To examine whether the $4 \%$ difference in the dropout rate between extreme quintiles explains away the observed performance difference across the SDI quintiles, we need to know the performance of the funds after they drop out. Unfortunately, such data are not readily available. Funds drop out of the database for many reasons, such as liquidations, mergers, name changes, or they voluntarily stop reporting. As a result, even the sign of the bias is not clear. We assess the potential impact of dropout bias through the following back-of-the-envelope calculations. For each portfolio, the true risk-adjusted return can be denoted as:

$$
\text { alpha }^{\text {True }}=w^{\text {Surviving }} \text { alpha } a^{\text {Surviving }}+w^{\text {Dropout }} \text { alpha }{ }^{\text {Dropout }}
$$

The difference in the true performance between the high and low SDI portfolios is then given by:

$$
\begin{aligned}
& \text { alpha }_{\mathrm{Hi}}^{\text {True }}-\text { alpha }_{\text {Low }}^{\text {True }}= \\
& w_{\mathrm{Hi}}^{\text {surviving }} \text { alpha }_{\mathrm{Hi}}^{\text {Surviving }}+w_{\mathrm{Hi}}^{\text {Dropout }} \text { alpha }_{\mathrm{Hi}}^{\text {Dropout }}-w_{\text {Low }}^{\text {surviving }} \text { alpha }_{\text {Low }}^{\text {Surving }}-w_{\text {Low }}^{\text {Dropout }} \text { alpha }_{\text {Low }}^{\text {Dropout }}
\end{aligned}
$$

Since there is no direct way to measure the performance of funds after they leave the database,

assuming $a l p h a_{\text {Low }}^{\text {Dropout }}=a l p h a_{H i}^{\text {Dropout }}=a l p h a^{\text {Dropout }}$, we will explore at what level alpha $^{\text {Dropout }}$ would eliminate the difference in the true performance between the high and low SDI portfolios.

Take the equally weighted 1-year post-formation case as an example. Based on Table 4A and Table 8, alpha ${ }_{H i}^{\text {True }}-$ alpha $_{\text {Low }}^{\text {True }}=0.80 \times 7.95 \%-0.84 \times 4.00 \%+(0.20-0.16)$ alpha $^{\text {Dropout }}$. As long as the annualized alpha $a^{\text {Dropout }} \geq-75 \%$ for funds 1 year after dropping out, the true performance of the high SDI portfolio beats that of the low SDI portfolio.

\section{Conclusion}

Investors want to identify talented hedge fund managers who have unique alpha-generating investment ideas. Since little information about funds’ security holdings or trading strategies is disclosed to investors, assessing managerial ability is a challenging task that relies mainly on 
learning from funds' historical return information and managers' track records. Academic literature has studied how past fund performance relates to future fund performance. In this paper, we examine a different aspect of fund historical returns, namely the extent to which a fund's return series resembles the return series of its peer funds. We hypothesize that skilled managers with innovative ideas will herd less frequently, and thus their returns will display less resemblance to those of an average fund.

To measure the distinctiveness of a fund's investment strategy, we estimate the correlation of a fund's returns with the average returns of its peer funds. We term ( 1 - correlation) the SDI. Using fund return data from January 1994 to December 2008, we document a substantial cross-sectional variation in the SDI, indicating much heterogeneity in the distinctive quality of funds' styles. We also find strong persistence in the individual funds' SDI for years into the future, suggesting that the SDI reflects persistent, fund-specific factors. Further analysis indicates that the SDI is related to a number of fund characteristics, for example, past fund performance, return volatility, fund age, size, the lengths of redemption notice period and lockup period, incentive fees, minimum investment, and leverage usage.

Our main result shows that $S D I$ is associated with significantly better future fund performance. Funds with a high SDI tend to perform consistently better, after adjusting for differences in their risks and styles. We show this finding using a portfolio approach, a panel regression approach, and the Fama-MacBeth method. Overall, our evidence indicates that the SDI is a potentially useful indicator of managerial innovative talent, and it can be used to good effect by investors in selecting funds. 


\section{Appendix A: Smoothing-adjusted Sharpe ratio}

We use the smoothing-adjusted Sharpe ratio, as opposed to the regular Sharpe ratio. Lo (2002) points out that hedge fund returns are subject to high serial correlations that can bias the annualized Sharpe Ratio, measured using monthly returns if autocorrelation in returns is not taken into account. Moreover, Getmansky, Lo, and Makarov (hereafter GLM, 2004) show that due to illiquidity and smoothing, the unobserved true economic returns differ from the observed smoothed returns. Therefore, even the monthly Sharpe ratio, which itself is based on the observed returns, will be biased. GLM (2004) further propose an econometric model of return smoothing, as well as an estimator for the smoothing-adjusted S. In particular, the true return of a hedge fund $\mathrm{R}_{\mathrm{t}}$ is determined by a linear factor model, as described below:

$$
R_{t}=\mu+\beta \Lambda_{t}+\varepsilon_{t}, \quad \varepsilon_{t}, \Lambda_{t} \sim I I D(\mathrm{~A} 1)
$$

The true return $\mathrm{R}_{\mathrm{t}}$ is not observable; instead we observed the smoothed returns $R_{t}^{o}$ as follows:

$$
\begin{aligned}
& R_{t}^{o}=\theta_{0} R_{t}+\theta_{1} R_{t-1}+\ldots+\theta_{k} R_{t-k} \\
& \theta_{j} \in[0,1], j=0, \ldots, k \text { and } \theta_{0}+\theta_{1}+\ldots \theta_{k}=1
\end{aligned}
$$

Our paper shows that the Sharpe ratio of the true unobserved return can be obtained by multiplying the regular Shaper ratio based on the smoothed return by $\sqrt{\theta_{0}^{2}+\theta_{1}^{2}+\ldots+\theta_{k}^{2}}$. The coefficients $\left(\theta_{0}, \theta_{1}, \ldots \theta_{k}\right)$ in Equation (A2) can be estimated by the maximum likelihood method. We assume that the observed returns depend on lagged true returns up to time $(\mathrm{t}-2)$. Thus, the smoothing-adjusted Sharpe ratio is

$$
S R=\sqrt{\theta_{0}^{2}+\theta_{1}^{2}+\theta_{2}^{2}} S R^{o}
$$

where $\mathrm{SR}^{0}$ is the regular Sharpe ratio calculated using observed monthly hedge fund returns. 


\section{Appendix B1: Comparing the TASS and Cluster Styles}

\section{Table B1: Cross-Tabulation of Self-Reported TASS Styles and Cluster Styles (200701-200812)}

Table B1 reports the cross-tabulation of cluster styles with the styles reported by hedge funds in TASS. The TASS styles are those attributed to the funds, as of December 2008. The clusters are obtained, based on hedge fund returns from January 2007 to December 2008.

\begin{tabular}{|c|c|c|c|c|c|c|c|c|c|c|c|}
\hline TASS Style/Cluster Style & 1 & 2 & 3 & 4 & 5 & 6 & 7 & 8 & 9 & 10 & $\begin{array}{l}\text { Row } \\
\text { Total }\end{array}$ \\
\hline Convertible Arbitrage & 0 & 17 & 2 & 11 & 1 & 34 & 12 & 6 & 2 & 9 & 94 \\
\hline Dedicated Short Bias & 0 & 0 & 18 & 0 & 0 & 0 & 0 & 0 & 1 & 0 & 19 \\
\hline Emerging Market & 0 & 3 & 3 & 6 & 72 & 35 & 72 & 14 & 4 & 9 & 218 \\
\hline Equity Market Neutral & 11 & 16 & 18 & 15 & 30 & 29 & 14 & 24 & 8 & 4 & 169 \\
\hline Event Driven & 4 & 28 & 10 & 93 & 43 & 35 & 10 & 38 & 13 & 30 & 304 \\
\hline Fixed Income & 9 & 22 & 13 & 13 & 6 & 34 & 16 & 6 & 3 & 22 & 144 \\
\hline Global Macro & 8 & 9 & 16 & 14 & 19 & 15 & 23 & 10 & 30 & 6 & 150 \\
\hline Long Short Equity & 38 & 61 & 37 & 219 & 267 & 45 & 162 & 113 & 43 & 69 & 1,054 \\
\hline Managed Future & 15 & 15 & 26 & 7 & 5 & 9 & 4 & 6 & 138 & 3 & 228 \\
\hline Multi Strategy & 7 & 29 & 13 & 22 & 89 & 38 & 27 & 38 & 30 & 23 & 316 \\
\hline Column Total & 92 & 200 & 156 & 400 & 532 & 274 & 340 & 255 & 272 & 175 & 2,696 \\
\hline
\end{tabular}




\section{Appendix B2: Test of Clustering Stability}

We study the stability of the clusters by looking at the pair-wise associations between funds in our sample. Ideally, funds currently clustered together due to fundamental links will stay clustered together in the next period if their strategies remain stable. At each time point, we define "connection" to be either 1 or 0 depending on whether the two funds fall into the same cluster or not. We then count the percentage of pair-wise connections that remain unchanged for the next year. A higher percentage of unchanged pair-wise connections indicate a more stable clustering. Table B2 gives the clustering stability results. Column 2 lists the number of pair-wise connections that stay the same, and column 3 lists the total number of pair-wise connections for funds that are alive in both sets of clusters. Column 4 gives the switching rate, the percentage of connections changed from the previous clustering results. The average annual switching rate is $16.2 \%$. To gauge the stability of the clustering over time, for each year, we bootstrap the switching rate under the null hypothesis of funds being grouped by random chance. The null is constructed by forming samples via random draws without replacement from actual fund returns. We follow Abraham, Goetzmann, and Wachter (1994) and Goetzmann and Wachter (1995) for the bootstrap procedure. For each round of the bootstrap procedure, we set the number of clusters and the total number of funds equal to those statistics from the real sample. Column 5 reports the average null switching rate for each year. The average rate of change under the null is $29.7 \%$, considerably higher than the sample switching rate of $16.2 \%$. Column 6 reports the standard deviation of the bootstrapped distribution. The switching rate is below the $1 \%$ critical value in the left tail of the bootstrapped distribution for each sample year. Therefore, we reject the null of random grouping. Overall, our clustering procedures, based on historical returns, capture the fundamental links across funds, and hence, the resulting clusters are stable over time. 


\section{Table B2: Switching Rate of Pair-Wise Connections between Funds}

Table B2 summarizes the pattern of the switching rate of fund clustering results. In each period, we study the pair-wise connection between funds; the connection takes the value of 1 or 0 , depending on whether the two funds under study fall into the same cluster or not. We then count the percentage of pair-wise connections remaining unchanged in the next period. The higher the percentage, the higher the stability of clustering. Column 2 lists the number of pair-wise connections that remain the same as the last period, and column 3 lists the total number of pair-wise connections for funds that exist in both periods. Column 4 is the sample switching rate. It computes the percentage of connections that changed since the last period. Column 5 reports the bootstrapped switching rate under the null of random grouping. The last column reports the standard deviation of the bootstrapped null distribution.

\begin{tabular}{lccccc}
\hline Year & $\begin{array}{c}\text { Unchanged } \\
\text { Pairs }\end{array}$ & $\begin{array}{c}\text { Total \# of } \\
\text { Pairs }\end{array}$ & $\begin{array}{c}\text { Sample } \\
\text { Switching Rate }\end{array}$ & $\begin{array}{c}\text { Null } \\
\text { Switching Rate }\end{array}$ & $\begin{array}{c}\text { Std. Dev. } \\
\text { (Null Switching Rate) }\end{array}$ \\
\hline 1996 & 94,889 & 111,156 & $14.63 \%$ & $29.37 \%$ & $0.24 \%$ \\
1997 & 143,159 & 167,910 & $14.74 \%$ & $29.90 \%$ & $0.21 \%$ \\
1998 & 215,418 & 258,840 & $16.78 \%$ & $29.75 \%$ & $0.19 \%$ \\
1999 & 347,701 & 403,651 & $13.86 \%$ & $29.94 \%$ & $0.22 \%$ \\
2000 & 468,646 & 570,846 & $17.90 \%$ & $29.39 \%$ & $0.23 \%$ \\
2001 & 609,122 & 708,645 & $14.04 \%$ & $29.49 \%$ & $0.24 \%$ \\
2002 & 757,753 & 899,811 & $15.79 \%$ & $29.74 \%$ & $0.21 \%$ \\
2003 & 939,498 & $1,128,753$ & $16.77 \%$ & $29.47 \%$ & $0.21 \%$ \\
2004 & $1,178,813$ & $1,407,003$ & $16.22 \%$ & $30.17 \%$ & $0.22 \%$ \\
2005 & $1,529,207$ & $1,842,240$ & $16.99 \%$ & $29.58 \%$ & $0.23 \%$ \\
2006 & $1,772,203$ & $2,143,485$ & $17.32 \%$ & $29.63 \%$ & $0.22 \%$ \\
2007 & $2,020,425$ & $2,521,135$ & $19.86 \%$ & $29.64 \%$ & $0.21 \%$ \\
2008 & $2,023,149$ & $2,536,878$ & $20.25 \%$ & $29.74 \%$ & $0.18 \%$ \\
& & & & & \\
Mean & & & $16.24 \%$ & $29.67 \%$ & \\
\hline
\end{tabular}




\section{References}

Abraham, J., Goetzmann, W., and Wachter, S., 1994, Homogeneous Groupings of Metropolitan Housing Markets, Journal of Housing Economics 3, 186-206.

Ackermann, C., McEnally, R., and Ravenscraft, D., 1999, The Performance of Hedge Funds: Risk, Return, and Incentives, Journal of Finance 54, 833-874.

Agarwal, V., Daniel, N., and Naik, N., 2007, Role of Managerial Incentives and Discretion in Hedge Fund Performance, forthcoming in Journal of Finance.

Agarwal, V., and Naik, N., 2000, Multi-Period Performance Persistence Analysis of Hedge Funds, Journal of Financial and Quantitative Analysis 35, 327-342.

Agarwal, V., and Naik, N., 2004, Risks and Portfolio Decisions Involving Hedge Funds, Review of Financial Studies 17, 63-98.

Aggarwal, R., and Jorion, P., 2009, The Risks of Emerging Hedge Fund Managers, Journal of Investing.

Aragon, G., 2007, Share Restriction and Asset Pricing: Evidence from the Hedge Fund Industry, Journal of Financial Economics 83, 33-58.

Berk, Jonathan B., and Green, R. C., 2004, Mutual Fund Flows and Performance in Rational Markets, Journal of Political Economy 112(6), 1269-1295.

Brown, S., and Goetzmann, W., 1997, Mutual Fund Styles, Journal of Financial Economics 43, 373-399.

Brown, S., and Goetzmann, W., 2003, Hedge Funds with Style, Journal of Portfolio Management 29, 101-112.

Brown, S., Goetzmann, W., and Ibbotson, R., 1999, Off-Shore Hedge Funds: Survival and Performance, Journal of Business 72, 91-117.

Brown, S., Goetzmann, W., Liang, B., and Schwarz, C., 2007, Mandatory Disclosure and Operational Risk: Evidence from Hedge Fund Registration, Journal of Finance, forthcoming.

Brown, S., Goetzmann, W., and Ross, S., 1995, Survival, Journal of Finance 50, 853-873.

Carhart, M., 1997, On Persistence in Mutual Fund Performance, Journal of Finance 52, 57-82.

Chen, J., Hong, H., Huang, M., and Kubik, J., 2004, Does Fund Size Erode Mutual Fund Performance? The Role of Liquidity and Organization, The American Economic Review 90(5), 1276-1302.

Cohen, R., Coval, J. D., and Pástor, L., 2005, Judging Fund Managers by the Company That They Keep, Journal of Finance 60, 1057-1096. 
Cremers M., and Petajisto A., 2007, How Active is Your Fund Manager? A New Measure That Predicts Performance, forthcoming in Review of Financial Studies.

Ding, B., Getmansky, M., Liang, B., and Wermers, R., 2008, Investor Flows and Share Restrictions in the Hedge Fund Industry, Working Paper.

Fung, W., and Hsieh, D., 1997, Empirical Characteristics of Dynamic Trading Strategies: The Case of Hedge Funds, Review of Financial Studies 10, 275-302.

Fung, W., and Hsieh, D., 2000, Performance Characteristics of Hedge Funds and CTA Funds: Natural Versus Spurious Biases, Journal of Financial and Quantitative Analysis 35, 291307.

Fung, W., and Hsieh, D., 2001, The Risk in Hedge Fund Strategies: Theory and Evidence from Trend Followers, Review of Financial Studies 14, 313-341.

Fung, W., and Hsieh, D., 2002, Benchmarks of Hedge Fund Performance: Information Content and Measurement Biases, Financial Analysts Journal 58, 22-34.

Fung, W., Hsieh, D., Naik, N., and Ramadorai, T., 2008, Hedge Funds: Performance, Risk, and Capital Formation, Journal of Finance, forthcoming.

Getmansky, M., Lo, A., and Makarov, I., 2004, An Econometric Model of Serial Correlation and Illiquidity in Hedge Fund Returns, Journal of Financial Economics 74, 529-609.

Goetzmann, W., Ingersoll, J., and Ross, S., 2003, High-Water Marks and Hedge Fund Management Contracts, Journal of Finance 58, 1685-1717.

Goetzmann, W., and Wachter, S., 1995, Clustering Methods for Real Estate Portfolios, Real Estate Economics 23, 271-310.

Griffin, J., and Xu, J., 2007, How Smart are the Smart Guys? A Unique View from Hedge Fund Stock Holdings, Review of Financial Studies, forthcoming.

Hunter, D., Kandel, E., Kandel, S., and Wermers, R., 2009, Endogenous Benchmarks, University of Maryland Working Paper.

Ibbotson, R., and Chen, P., 2006, The A,B,Cs of Hedge Funds: Alphas, Betas, and Costs, Yale ICF Working Paper No. 06-10.

Jagannathan R., Malakhov, A., and Novikov, D., 2006, Do Hot Hands Exist Among Hedge Fund Managers? An Empirical Evaluation, NBER Working Paper Series, Vol. w12015.

Kacperczyk, M., and Seru, A., 2007, Fund Manager User of Public Information: New Evidence on Managerial Skills, Journal of Finance 62, 485-528.

Kacperczyk, M., Sialm, C., and Zheng, L., 2005. On the Industry Concentration of Actively Managed Equity Mutual Funds, Journal of Finance 60, 1983-2011.

Kacperczyk, M., Sialm, C., and Zheng, L., 2007. Unobserved Actions of Mutual Funds, Review of Financial Studies, forthcoming. 
Kosowski, R., Naik, N. Y., and Teo, M., 2007, Do Hedge Funds Deliver Alpha? A Bayesian and Bootstrap Analysis, Journal of Financial Economics 84, 229-264.

Li, H., Zhang, X., and Zhao, R., 2007, Investing in Talents: Manager Characteristics and Hedge Fund Performances, Working Paper, University of Michigan.

Liang, B., 1999, On the Performance of Hedge Funds, Financial Analysts Journal 55, 72-85.

Liang, B., 2000, Hedge Funds: The Living and the Dead, Journal of Financial and Quantitative Analysis 35, 309-326.

Liang, B., and Park, H., 2008, Share Restriction, Liquidity Premium, and Offshore Hedge Funds, Working Paper, University of Massachusetts.

Lo, A., 2002, The Statistics of Sharpe Ratios, Financial Analysts Journal 58, 36-52.

Malkiel, B., and Saha, A., 2005, Hedge Fund: Risk and Return, Financial Analysts Journal 61, No. 6: 80-88.

Petersen, M., 2005, Estimating Standard Errors in Finance Panel Data Sets: Comparing Approaches, Working Paper, Northwestern University.

Titman, S., and Tiu, C., 2008, Do the Best Hedge Funds Hedge? Working Paper, University of Texas at Austin.

Treynor, J., and Black, F., 1973, How to Use Security Analysis to Improve Portfolio Selection, Journal of Business 46, 66-86. 


\section{Figure 1: Histogram of Hedge Fund SDI}

Figure 1A represents the histogram of the SDI based on the cluster styles for all funds from 1996-2008. It also depicts a breakdown between the live and graveyard funds in the distribution. Figure $1 \mathrm{~B}$ represents the histogram of the SDI based on the TASS styles.
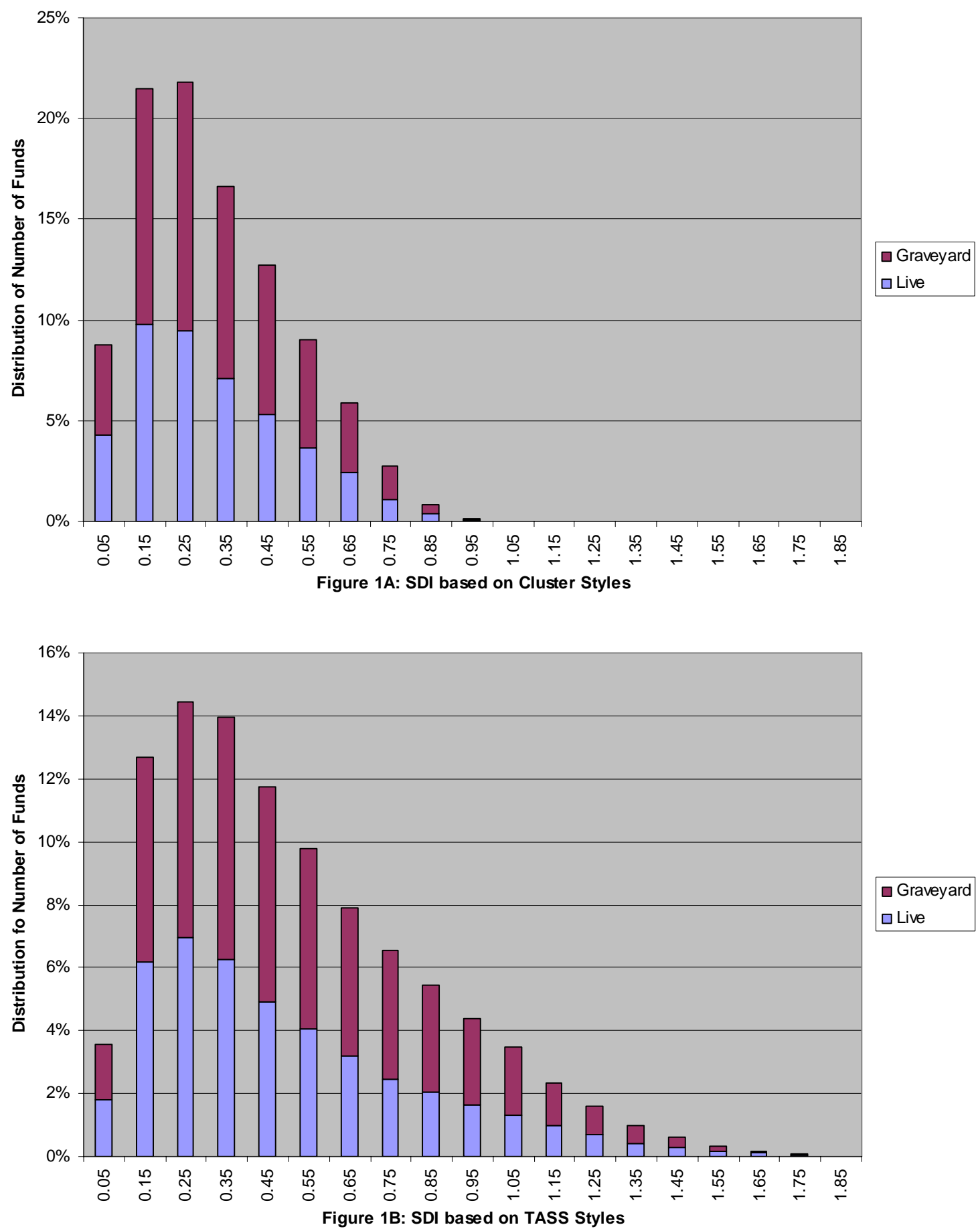
Figure 2: Histogram of Hedge Fund SDI

Figure 2 represents the relative distribution of numbers of funds across the cluster styles for the SDI bins.

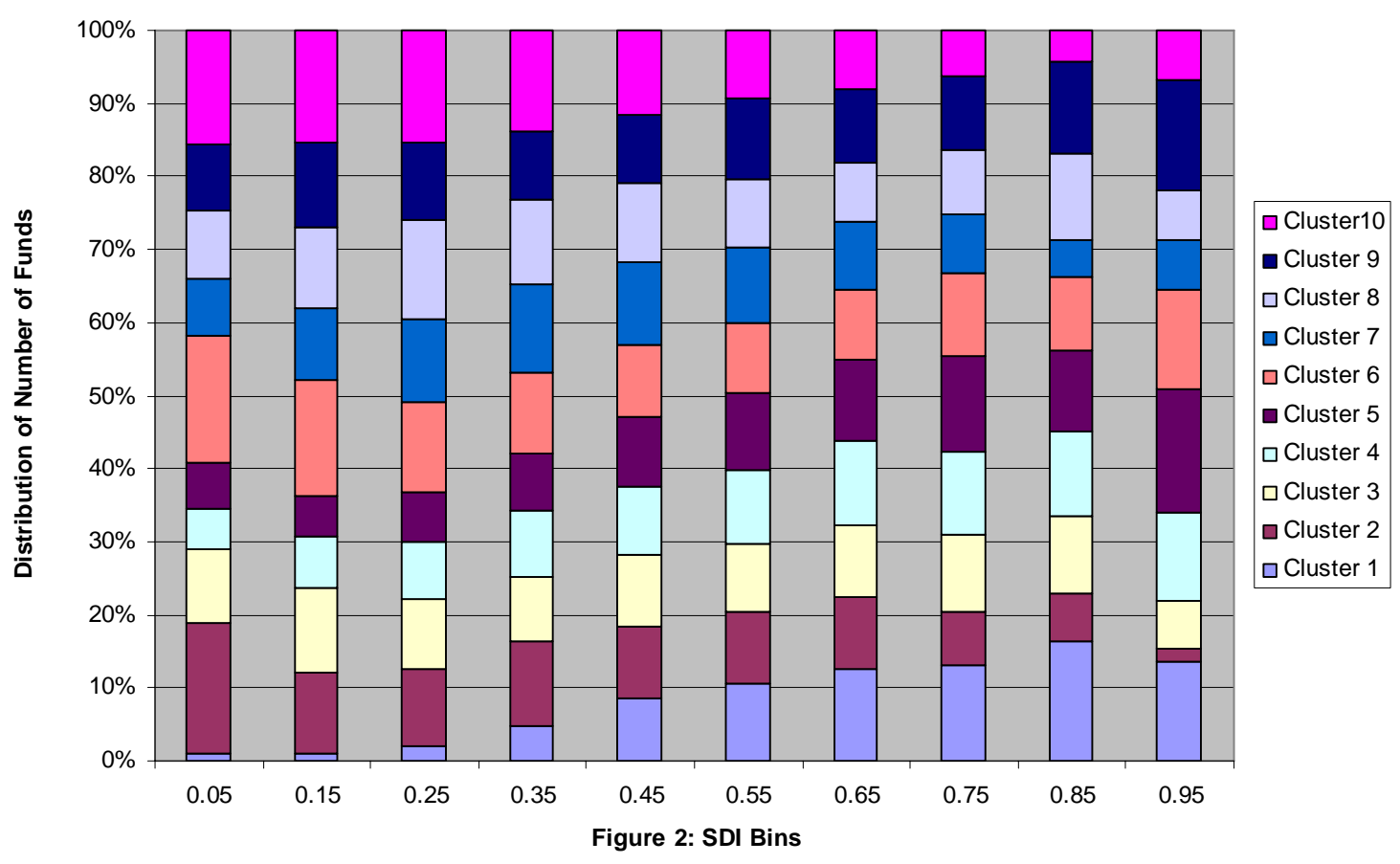




\section{Table 1: Summary Statistics (1996-2008)}

Panel A summarizes the time-series average of cross-sectional summary statistics for the main variables for the full sample, and for the live and graveyard fund subsamples. Variables considered are number of funds per period, the $S D I$, measured as (1 - correlation) from the clustering program, and contemporaneous fund characteristics including monthly net of fee returns, FH7-factor adjusted alphas and the corresponding appraisal ratio (AR), Sharpe ratio (SR), volatility of monthly net fee returns $(\mathrm{Vol})$, lengths of redemption notice periods and lockup periods, dummy variables for personal capital commitment and high water mark, management fees, incentive fees, fund age, $A U M$, new money flow into funds within the past 12 months as a fraction of $A U M$, minimum investment, and dummy for leverage usage. Panel B reports the time-series average of the pair-wise correlation between these variables.

\begin{tabular}{|c|c|c|c|c|c|c|c|c|c|c|c|c|c|c|c|c|c|}
\hline \multicolumn{18}{|c|}{ Panel A: Fund Performance and Characteristics } \\
\hline & \multicolumn{3}{|c|}{$\begin{array}{l}\text { Full Sample (3539 unique funds) } \\
\text { Median } \quad \text { Min Max }\end{array}$} & & Std & & Mean & Median & Min & $\operatorname{Max}$ & Std & & Mean & Median & Min & Max & Std \\
\hline \#Funds per period & 1011 & 1024 & 291 & 1657 & 420 & & 440 & 333 & 69 & 1348 & 346 & & 571 & 615 & 130 & 822 & 188 \\
\hline SDI & 0.32 & 0.29 & 0.00 & 0.90 & 0.18 & & 0.31 & 0.28 & 0.00 & 0.85 & 0.18 & & 0.33 & 0.29 & 0.00 & 0.89 & 0.18 \\
\hline NetFeeRet(\% p.m.) & 0.96 & 0.72 & -24.87 & 64.88 & 5.34 & & 1.15 & 0.86 & -16.88 & 23.92 & 4.46 & & 0.82 & 0.63 & -22.10 & 62.25 & 5.54 \\
\hline Alpha(\% p.m.) & 0.75 & 0.69 & -5.92 & 32.05 & 1.83 & & 0.84 & 0.75 & -3.67 & 8.51 & 1.32 & & 0.69 & 0.65 & -5.82 & 30.72 & 2.00 \\
\hline AR & 0.53 & 0.39 & -2.01 & 7.72 & 0.82 & & 0.54 & 0.41 & -1.38 & 5.51 & 0.76 & & 0.53 & 0.39 & -1.92 & 7.39 & 0.87 \\
\hline $\mathrm{SR}$ & 0.23 & 0.13 & -1.64 & 7.62 & 0.68 & & 0.25 & 0.16 & -1.22 & 5.26 & 0.66 & & 0.22 & 0.11 & -1.51 & 6.86 & 0.70 \\
\hline Vol(\%p.m) & 3.89 & 3.15 & 0.08 & 92.21 & 4.37 & & 3.96 & 3.29 & 0.12 & 23.63 & 2.99 & & 3.81 & 3.02 & 0.10 & 85.58 & 4.83 \\
\hline RedemptionNoticePeriod(days) & 34.07 & 28.94 & 0.00 & 180.00 & 26.44 & & 36.55 & 30.00 & 0.00 & 180.00 & 28.71 & & 33.98 & 28.04 & 0.00 & 160.38 & 25.26 \\
\hline Lockup(months) & 3.52 & 0.00 & 0.00 & 56.42 & 6.30 & & 4.19 & 0.00 & 0.00 & 55.44 & 7.09 & & 3.31 & 0.00 & 0.00 & 32.42 & 5.81 \\
\hline PersonalCapDummy & 0.47 & 0.40 & 0.00 & 1.00 & 0.49 & & 0.50 & 0.53 & 0.00 & 1.00 & 0.49 & & 0.44 & 0.38 & 0.00 & 1.00 & 0.48 \\
\hline HighWaterMarkDummy & 0.54 & 0.56 & 0.00 & 1.00 & 0.46 & & 0.61 & 0.96 & 0.00 & 1.00 & 0.48 & & 0.52 & 0.54 & 0.00 & 1.00 & 0.45 \\
\hline MgmtFee(\%) & 1.42 & 1.16 & 0.00 & 7.10 & 0.75 & & 1.49 & 1.33 & 0.00 & 6.77 & 0.77 & & 1.38 & 1.12 & 0.00 & 6.17 & 0.72 \\
\hline IncentiveFee(\%) & 18.13 & 20.00 & 0.00 & 49.36 & 5.89 & & 18.95 & 20.00 & 0.00 & 34.84 & 4.52 & & 17.80 & 20.00 & 0.00 & 49.23 & 6.37 \\
\hline Age(years) & 6.54 & 5.55 & 2.50 & 32.06 & 3.71 & & 6.97 & 5.90 & 2.51 & 25.21 & 4.03 & & 6.25 & 5.33 & 2.50 & 31.66 & 3.46 \\
\hline AUM(M\$) & 190.22 & 57.85 & 5.00 & 6965.16 & 482.28 & & 219.96 & 69.40 & 5.16 & 5314.59 & 513.20 & & 176.63 & 51.92 & 5.03 & 6634.38 & 472.96 \\
\hline Flowpast1Y(\%p.a.) & 18.03 & 0.14 & -161.48 & 819.06 & 82.55 & & 22.09 & 3.38 & -107.57 & 673.66 & 79.25 & & 15.22 & -1.47 & -146.22 & 749.21 & 82.55 \\
\hline MinInvestment(M\$) & 0.97 & 0.56 & 0.00 & 35.58 & 1.87 & & 1.13 & 0.53 & 0.00 & 31.92 & 2.31 & & 0.92 & 0.65 & 0.00 & 21.83 & 1.50 \\
\hline Leverage & 0.64 & 1.00 & 0.00 & 1.00 & 0.48 & & 0.68 & 1.00 & 0.00 & 1.00 & 0.46 & & 0.63 & 1.00 & 0.00 & 1.00 & 0.48 \\
\hline \multirow[t]{4}{*}{ Panel B: Correlations } & & & & & & & & & & & & & & & & & \\
\hline & & & & & & & $\begin{array}{l}\text { Redemp- } \\
\text { tion }\end{array}$ & & Personalc & HighWater & & & & & & & \\
\hline & & NetFee & & & & & NoticePeri & & ap & Mark & & IncentiveF & & & MinInvest & & \\
\hline & SDI & Ret & Alpha & AR & $\mathrm{SR}$ & Vol & od & Lockup & Dummy & Dummy & Mgmt Fee & ee & Age & AUM & ment & Leverage & \\
\hline NetFeeRet(\% p.m.) & -0.01 & & & & & & & & & & & & & & & & \\
\hline Alpha(\% p.m.) & 0.16 & 0.34 & & & & & & & & & & & & & & & \\
\hline AR & 0.18 & 0.15 & 0.83 & & & & & & & & & & & & & & \\
\hline SR & 0.16 & 0.34 & 1.00 & 0.83 & & & & & & & & & & & & & \\
\hline Vol(\%p.m) & -0.16 & 0.42 & -0.24 & -0.28 & -0.24 & & & & & & & & & & & & \\
\hline RedemptionNoticePeriod(days) & 0.05 & 0.04 & 0.23 & 0.22 & 0.23 & -0.15 & & & & & & & & & & & \\
\hline Lockup(months) & -0.02 & 0.07 & 0.07 & 0.05 & 0.07 & 0.00 & 0.31 & & & & & & & & & & \\
\hline PersonalCapDummy & 0.02 & 0.01 & -0.02 & -0.03 & -0.02 & 0.03 & 0.03 & -0.01 & & & & & & & & & \\
\hline HighWaterMarkDummy & 0.01 & 0.05 & 0.10 & 0.09 & 0.10 & -0.05 & 0.25 & 0.28 & -0.10 & & & & & & & & \\
\hline MgmtFee(\%) & -0.02 & 0.06 & -0.06 & -0.06 & -0.06 & 0.14 & -0.20 & -0.13 & -0.08 & -0.12 & & & & & & & \\
\hline IncentiveFee(\%) & 0.10 & 0.06 & 0.06 & 0.06 & 0.06 & 0.04 & 0.12 & 0.09 & 0.08 & 0.22 & 0.01 & & & & & & \\
\hline Age(years) & -0.05 & -0.03 & -0.06 & -0.06 & -0.06 & 0.02 & -0.08 & -0.04 & 0.13 & -0.18 & 0.04 & -0.10 & & & & & \\
\hline AUM(M\$) & -0.02 & 0.05 & 0.10 & 0.08 & 0.10 & -0.05 & 0.08 & 0.04 & 0.03 & 0.01 & 0.01 & -0.03 & 0.16 & & & & \\
\hline Flowpast1Y(\%р.а.) & 0.04 & 0.11 & 0.11 & 0.07 & 0.11 & -0.03 & 0.02 & 0.02 & -0.02 & 0.05 & 0.01 & 0.02 & -0.07 & 0.03 & & & \\
\hline Minlnvestment(M\$) & 0.04 & 0.01 & 0.16 & 0.17 & 0.16 & -0.12 & 0.17 & 0.12 & 0.04 & 0.17 & -0.05 & 0.06 & 0.05 & 0.21 & 0.01 & & \\
\hline Leverage & 0.04 & 0.02 & 0.02 & 0.01 & 0.02 & 0.04 & -0.05 & -0.07 & 0.14 & 0.02 & 0.08 & 0.16 & 0.01 & 0.04 & 0.01 & -0.02 & \\
\hline
\end{tabular}


Table 2: Persistence of the SDI (1996-2008)

Table 2 reports the time-series means of the average SDI for the current quarter and the subsequent 3 months, 6 months, and 1-3 years for each of the quintile portfolios sorted on the previous 24-month SDI. It also reports the difference between the high and low portfolios and the corresponding $t$-statistics. Also reported are the time-series means of number of funds per period at the sorting and at the end of each holding horizon.

\begin{tabular}{|c|c|c|c|c|c|c|}
\hline \multirow{2}{*}{\multicolumn{7}{|c|}{ Time 0}} \\
\hline & & & & & & \\
\hline Low SDI Port & 0.10 & 0.14 & 0.16 & 0.19 & 0.23 & 0.24 \\
\hline Port2 & 0.20 & 0.22 & 0.23 & 0.25 & 0.26 & 0.26 \\
\hline Port3 & 0.29 & 0.30 & 0.31 & 0.31 & 0.31 & 0.30 \\
\hline Port4 & 0.41 & 0.41 & 0.40 & 0.39 & 0.37 & 0.36 \\
\hline Hi SDI Port & 0.61 & 0.56 & 0.54 & 0.50 & 0.45 & 0.44 \\
\hline Hi-Lo (SDI) & $0.51^{\star \star \star}$ & $0.43^{\star \star \star}$ & $0.38^{\star \star \star}$ & $0.31^{\star \star \star}$ & $0.22^{\star \star \star}$ & $0.20^{\star \star \star \star}$ \\
\hline tstat & 121.51 & 68.19 & 47.23 & 29.32 & 19.23 & 24.17 \\
\hline \#Funds & 1006 & 964 & 919 & 835 & 700 & 588 \\
\hline
\end{tabular}

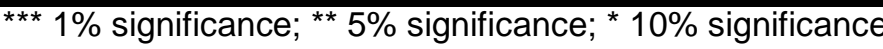


Table 3: Determinants of the SDI (1996-2008)

Table 3 reports the estimates of the following panel regression of the SDI on lagged fund characteristics using annual data: $S D I_{i, t}=c_{0 i}+c_{1 i}$ Control $_{i, t-1}+e_{i, t}$. Survivorship and backfill biases are controlled for to the extent the data allow. The $S D I$ is measured as ( 1 - correlation) from the clustering procedures. Lagged fund characteristics are measured over the preceding 24-month period including FH7 alpha and the corresponding appraisal ratio $(A R)$, Sharpe ratio $(S R)$, volatility of net fee returns $(\mathrm{Vol})$, lengths of redemption notice periods and lockup periods, dummy variables for personal capital commitment and high water mark, management fees, incentive fees, fund age, $A U M$, new money flow into funds as a fraction of AUM, minimum investment, dummy for leverage usage. The coefficients are multiplied by 100 . The $t-$ statistics reported in italics are adjusted for fund-clustering effect and time- and cluster style-fixed effects.

\begin{tabular}{|c|c|c|c|c|}
\hline & 1 & II & III & IV \\
\hline VolPast2Y(\%p.m.) & $-0.48^{\star \star}$ & $-0.58^{\star \star}$ & -0.12 & -0.15 \\
\hline$t$-stat & -2.00 & -2.29 & -0.46 & -0.55 \\
\hline \multirow[t]{2}{*}{ RedemptionNoticePeriod(30 Days) } & $0.70^{*}$ & 0.60 & 0.25 & 0.36 \\
\hline & 1.88 & 1.61 & 0.70 & 1.03 \\
\hline \multirow[t]{2}{*}{ Lockup(months) } & $-0.07^{*}$ & $-0.08^{\star}$ & -0.07 & -0.07 \\
\hline & -1.71 & -1.78 & -1.59 & -1.62 \\
\hline \multirow[t]{2}{*}{ PersonalCapitalDummy } & 0.61 & 0.73 & 0.77 & 0.69 \\
\hline & 1.05 & 1.28 & 1.34 & 1.19 \\
\hline \multirow[t]{2}{*}{ HighWaterMarkDummy } & $-1.49 \star \star$ & $-1.43^{\star \star}$ & $-1.36 \star \star$ & $-1.37^{\star \star}$ \\
\hline & -2.18 & -2.10 & -2.00 & -2.01 \\
\hline \multirow[t]{2}{*}{ MgmtFee(\%) } & -0.07 & -0.09 & -0.07 & -0.07 \\
\hline & -0.15 & -0.21 & -0.17 & -0.16 \\
\hline \multirow[t]{2}{*}{ Incentive Fee(\%) } & $0.29 * \star \star$ & $0.28^{\star \star \star}$ & $0.28^{\star \star \star}$ & $0.29^{\star \star \star}$ \\
\hline & 5.13 & 5.20 & 5.17 & 5.09 \\
\hline \multirow[t]{2}{*}{ Age(years) } & $-0.14^{\star \star}$ & $-0.12^{*}$ & $-0.11^{*}$ & $-0.14^{\star \star}$ \\
\hline & -2.08 & -1.76 & -1.67 & -2.00 \\
\hline \multirow[t]{2}{*}{$\ln (A \cup M)$} & $-1.01^{\star \star \star}$ & $-1.05^{\star \star \star}$ & $-1.09 * \star \star$ & $-1.08^{\star \star \star}$ \\
\hline & -5.09 & -5.22 & -5.66 & -5.43 \\
\hline \multirow[t]{2}{*}{ FlowPast2Y in \% } & $0.01^{\star \star \star}$ & $0.01^{\star \star \star}$ & $0.01^{\star \star \star}$ & $0.01^{\star \star *}$ \\
\hline & 3.38 & 3.08 & 3.05 & 3.07 \\
\hline \multirow[t]{2}{*}{ In(MinInvestment+1) } & $0.78^{\star \star \star}$ & $0.75^{\star \star \star}$ & $0.74^{\star \star \star}$ & $0.77^{\star \star \star}$ \\
\hline & 3.60 & 3.45 & 3.46 & 3.54 \\
\hline \multirow[t]{2}{*}{ Leverage } & $1.01^{*}$ & $1.00 *$ & $0.99 *$ & 0.92 \\
\hline & 1.76 & 1.77 & 1.74 & 1.60 \\
\hline \multirow[t]{2}{*}{ AvgPast2YRet(\% p.m.) } & $1.22^{\star \star \star}$ & & & \\
\hline & 6.69 & & & \\
\hline \multirow[t]{2}{*}{ AlphaPast2Y(\%p.m) } & & $1.57^{\star \star \star}$ & & \\
\hline & & 9.16 & & \\
\hline \multirow[t]{2}{*}{ ARPast2Y } & & & $3.11^{\star \star \star}$ & \\
\hline & & & 8.15 & \\
\hline \multirow[t]{2}{*}{ SRpast2Y } & & & & $4.70^{\star \star \star}$ \\
\hline & & & & 7.53 \\
\hline $\operatorname{AdjR2(\% )~}$ & 10.64 & 11.65 & 11.69 & 11.44 \\
\hline \#FundYearObs. & 12,911 & 12,911 & 12,874 & 12,907 \\
\hline
\end{tabular}

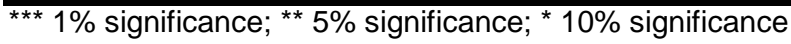




\section{Table 4: Portfolio Performance Based on the SDI (1996-2008)}

Table 4 reports the time-series means and t-statistics of the post-formation FH7 alphas, FH7 based appraisal ratios (AR), and the smoothing-adjusted Sharpe ratios $(S R)$, for the quintile portfolios sorted on the $S D I$. The performance measures are based on the equally and value weighted buy-and-hold portfolios sorted every 3 months and held for 3 months, 6 months, and 1-3 years. The SDI is measured as ( 1 - correlation), estimated using the clustering procedure. The $t$ statistics reported below in italics are adjusted for heteroscedasticity and autocorrelation.

\begin{tabular}{|c|c|c|c|c|c|c|c|c|c|c|c|c|c|c|c|}
\hline & \multicolumn{5}{|c|}{ Alpha_FH7 } & \multicolumn{5}{|c|}{ AppraisalRatio } & \multicolumn{5}{|c|}{$\begin{array}{l}\text { SharpeRatio(smoothing adjusted) } \\
\end{array}$} \\
\hline & $3 \mathrm{~m}(\%$ p.q.) & $6 \mathrm{~m}(\%$ p.sa.) & $1 y$ (\%p.a) & $2 y(\%$ p.2y.) & $3 y(\%$ p.3y.) & $3 \mathrm{~m}$ & $6 \mathrm{~m}$ & $1 \mathrm{y}$ & $2 y$ & $3 y$ & $3 \mathrm{~m}$ & $6 \mathrm{~m}$ & $1 y$ & $2 y$ & $3 y$ \\
\hline \multicolumn{16}{|c|}{ Panel A: Equally Weighted Portfolios } \\
\hline $\begin{array}{c}\text { LowSDIPort } \\
\text { tstat }\end{array}$ & $\begin{array}{l}1.03^{\star *} \\
2.29\end{array}$ & $\begin{array}{l}1.70^{* *} \\
1.99\end{array}$ & $\begin{array}{c}4.00^{* * *} \\
3.01\end{array}$ & $\begin{array}{l}8.66^{* * *} \\
5.02\end{array}$ & $\begin{array}{c}13.81 \star \star \star \\
7.91\end{array}$ & $\begin{array}{c}0.23^{* * *} \\
3.44\end{array}$ & $\begin{array}{c}0.16^{* * *} \\
3.39\end{array}$ & $\begin{array}{c}0.15^{\star * \star} \\
4.03\end{array}$ & $\begin{array}{c}0.14^{\star \star *} \\
4.92\end{array}$ & $\begin{array}{c}0.12^{\star \star \star} \\
6.23\end{array}$ & $\begin{array}{c}0.21^{\star * *} \\
2.36\end{array}$ & $\begin{array}{c}0.14^{\star \star *} \\
2.25\end{array}$ & $\begin{array}{c}0.13^{* \star *} \\
2.77\end{array}$ & $\begin{array}{c}0.11^{\star \star \star} \\
3.73\end{array}$ & $\begin{array}{c}0.10^{* \star *} \\
4.35\end{array}$ \\
\hline $\begin{array}{l}\text { Port2 } \\
\text { tstat }\end{array}$ & $\begin{array}{c}1.43^{* * *} \\
3.92\end{array}$ & $\begin{array}{c}2.61^{\star * *} \\
3.87\end{array}$ & $\begin{array}{c}5.29^{* * *} \\
4.82\end{array}$ & $\begin{array}{c}11.08^{\star \star \star} \\
7.07\end{array}$ & $\begin{array}{c}17.68^{\star \star \star} \\
12.48\end{array}$ & $\begin{array}{c}0.31^{* * *} \\
5.43\end{array}$ & $\begin{array}{c}0.23^{* \star \star} \\
5.77\end{array}$ & $\begin{array}{c}0.21^{* \star \star} \\
6.79\end{array}$ & $\begin{array}{c}0.18^{* * \star} \\
7.50\end{array}$ & $\begin{array}{c}0.17^{* * *} \\
8.67\end{array}$ & $\begin{array}{c}0.29^{\star * *} \\
3.80\end{array}$ & $\begin{array}{c}0.19^{* * \star} \\
3.51\end{array}$ & $\begin{array}{c}0.16^{* \star *} \\
3.77\end{array}$ & $\begin{array}{c}0.14^{\star \star *} \\
4.92\end{array}$ & $\begin{array}{c}0.13^{\star \star \star} \\
5.41\end{array}$ \\
\hline $\begin{array}{l}\text { Port3 } \\
\text { tstat }\end{array}$ & $\begin{array}{c}1.78^{* \star \star} \\
4.78\end{array}$ & $\begin{array}{c}3.35^{\star * *} \\
4.62\end{array}$ & $\begin{array}{l}7.14^{* \star *} \\
5.75\end{array}$ & $\begin{array}{c}14.95^{* \star *} \\
10.19\end{array}$ & $\begin{array}{c}21.66^{\star \star *} \\
19.64\end{array}$ & $\begin{array}{c}0.41^{\star \star \star} \\
8.59\end{array}$ & $\begin{array}{c}0.30^{\star \star \star \star} \\
7.90\end{array}$ & $\begin{array}{c}0.27^{\star \star \star} \\
9.88\end{array}$ & $\begin{array}{l}0.25^{\star \star *} \\
11.54\end{array}$ & $\begin{array}{l}0.22^{\star \star \star} \\
11.83\end{array}$ & $\begin{array}{c}0.31^{\star * \star} \\
4.40\end{array}$ & $\begin{array}{l}0.22^{\star \star \star} \\
4.27\end{array}$ & $\begin{array}{l}0.18^{\star \star \star} \\
4.63\end{array}$ & $\begin{array}{l}0.17^{* \star *} \\
6.16\end{array}$ & $\begin{array}{l}0.15^{\star * \star} \\
6.50\end{array}$ \\
\hline $\begin{array}{l}\text { Port4 } \\
\text { tstat }\end{array}$ & $\begin{array}{l}1.89^{* \star \star} \\
5.34\end{array}$ & $\begin{array}{l}3.87^{\star \star \star \star} \\
5.17\end{array}$ & $\begin{array}{l}7.49 * * \star \\
7.03\end{array}$ & $\begin{array}{c}15.14^{\star \star \star *} \\
13.07\end{array}$ & $\begin{array}{c}22.16^{\star \star \star} \\
22.38\end{array}$ & $\begin{array}{c}0.51^{\star \star \star \star} \\
9.55\end{array}$ & $\begin{array}{l}0.40^{\star \star \star *} \\
8.74\end{array}$ & $\begin{array}{l}0.33^{\star \star *} \\
10.61\end{array}$ & $\begin{array}{l}0.29^{* \star \star} \\
16.37\end{array}$ & $\begin{array}{l}0.26^{* \star \star} \\
19.58\end{array}$ & $\begin{array}{l}0.36^{* * \star} \\
5.76\end{array}$ & $\begin{array}{l}0.26^{\star \star \star} \\
5.75\end{array}$ & $\begin{array}{l}0.21^{\star \star \star} \\
5.91\end{array}$ & $\begin{array}{c}0.18^{\star \star \star} \\
9.01\end{array}$ & $\begin{array}{c}0.16^{\star \star \star} \\
9.25\end{array}$ \\
\hline $\begin{array}{l}\text { HiSDIPort } \\
\text { tstat }\end{array}$ & $\begin{array}{c}1.92^{\star \star \star} \\
7.88\end{array}$ & $\begin{array}{c}3.82^{\star \star \star \star} \\
7.40\end{array}$ & $\begin{array}{c}7.95^{* * \star} \\
8.59\end{array}$ & $\begin{array}{c}15.14^{\star \star \star} \\
12.50\end{array}$ & $\begin{array}{c}21.82^{\star \star \star} \\
17.65\end{array}$ & $\begin{array}{l}0.58^{\star \star \star} \\
10.31\end{array}$ & $\begin{array}{l}0.47^{\star \star \star} \\
10.93\end{array}$ & $\begin{array}{l}0.41^{\star \star \star} \\
13.71\end{array}$ & $\begin{array}{l}0.35^{* * *} \\
20.34\end{array}$ & $\begin{array}{l}0.32^{\star \star *} \\
20.62\end{array}$ & $\begin{array}{c}0.43^{* \star \star} \\
9.32\end{array}$ & $\begin{array}{l}0.31^{\star \star \star} \\
10.47\end{array}$ & $\begin{array}{l}0.25^{\star * \star} \\
11.95\end{array}$ & $\begin{array}{l}0.20^{* * *} \\
13.06\end{array}$ & $\begin{array}{l}0.17^{* \star *} \\
13.28\end{array}$ \\
\hline $\begin{array}{c}\text { Hi-Low } \\
\text { tstat } \\
\text { Annualized } \\
\text { FH7 Alpha }\end{array}$ & $\begin{array}{l}0.89^{\star *} \\
2.17\end{array}$ & $\begin{array}{c}2.12^{* * *} \\
3.09\end{array}$ & $\begin{array}{c}3.95^{\star \star *} \\
3.80\end{array}$ & $\begin{array}{l}6.48^{* * *} \\
5.88\end{array}$ & $\begin{array}{l}8.02^{* * *} \\
5.22\end{array}$ & $\begin{array}{c}0.35 * * \star \\
4.11\end{array}$ & $\begin{array}{c}0.31^{* * *} \\
5.20\end{array}$ & $\begin{array}{l}0.26^{* * *} \\
5.57\end{array}$ & $\begin{array}{c}0.22^{* * *} \\
7.71\end{array}$ & $\begin{array}{c}0.20^{* * \star} \\
8.99\end{array}$ & $\begin{array}{c}0.22^{\star * *} \\
3.01\end{array}$ & $\begin{array}{c}0.16^{\star \star *} \\
3.46\end{array}$ & $\begin{array}{c}0.12^{\star \star \star} \\
3.48\end{array}$ & $\begin{array}{c}0.09^{* \star \star} \\
3.68\end{array}$ & $\begin{array}{c}0.07^{\star * \star} \\
3.98\end{array}$ \\
\hline Hi-Low(\%p.a.) & $3.63^{\star \star \star}$ & $4.29 * \star \star$ & $3.95^{* \star \star}$ & $3.19^{* \star *}$ & $2.60^{* * *}$ & & & & & & & & & & \\
\hline \multicolumn{16}{|c|}{ Panel B: Value Weighted Portfolios } \\
\hline $\begin{array}{l}\text { LowSDIPort } \\
\text { tstat }\end{array}$ & $\begin{array}{l}1.00^{*} \\
1.94\end{array}$ & $\begin{array}{l}1.57 \\
1.58\end{array}$ & $\begin{array}{l}3.86^{\star *} \\
2.37\end{array}$ & $\begin{array}{c}8.46^{* \star *} \\
4.09\end{array}$ & $\begin{array}{c}14.54^{* \star *} \\
7.56\end{array}$ & $\begin{array}{c}0.29^{\star \star \star} \\
3.09\end{array}$ & $\begin{array}{l}0.22^{\star \star *} \\
3.28\end{array}$ & $\begin{array}{c}0.22^{* \star \star} \\
3.95\end{array}$ & $\begin{array}{c}0.21^{* \star *} \\
4.97\end{array}$ & $\begin{array}{c}0.20^{* \star *} \\
6.34\end{array}$ & $\begin{array}{c}0.26^{\star *} \\
2.36\end{array}$ & $\begin{array}{c}0.19^{* \star *} \\
2.61\end{array}$ & $\begin{array}{c}0.18^{\star \star \star} \\
3.13\end{array}$ & $\begin{array}{c}0.15^{* \star \star} \\
4.08\end{array}$ & $\begin{array}{c}0.14^{\star \star \star} \\
4.99\end{array}$ \\
\hline $\begin{array}{l}\text { Port2 } \\
\text { tstat }\end{array}$ & $\begin{array}{c}1.55^{\star \star \star} \\
3.48\end{array}$ & $\begin{array}{c}2.60^{\star \star \star} \\
2.85\end{array}$ & $\begin{array}{c}4.55^{\star \star \star} \\
2.93\end{array}$ & $\begin{array}{c}9.22^{\star \star \star} \\
3.38\end{array}$ & $\begin{array}{c}15.48^{\star \star \star} \\
4.59\end{array}$ & $\begin{array}{c}0.44^{\star \star \star} \\
5.27\end{array}$ & $\begin{array}{c}0.33^{\star \star \star} \\
5.54\end{array}$ & $\begin{array}{c}0.27^{\star * \star} \\
6.06\end{array}$ & $\begin{array}{c}0.25^{\star \star \star} \\
5.65\end{array}$ & $\begin{array}{c}0.24^{\star \star \star} \\
5.74\end{array}$ & $\begin{array}{c}0.40^{\star \star \star *} \\
4.33\end{array}$ & $\begin{array}{c}0.27^{\star \star \star} \\
3.75\end{array}$ & $\begin{array}{c}0.21^{\star \star \star} \\
3.78\end{array}$ & $\begin{array}{c}0.20^{\star \star \star} \\
5.06\end{array}$ & $\begin{array}{c}0.19^{\star * *} \\
5.64\end{array}$ \\
\hline $\begin{array}{l}\text { Port3 } \\
\text { tstat }\end{array}$ & $\begin{array}{c}1.76^{\star \star \star} \\
3.26\end{array}$ & $\begin{array}{c}3.57^{\star \star \star \star} \\
3.78\end{array}$ & $\begin{array}{l}7.93^{* \star *} \\
4.86\end{array}$ & $\begin{array}{c}16.00^{\star \star \star *} \\
6.11\end{array}$ & $\begin{array}{c}22.42^{\star \star \star} \\
9.64\end{array}$ & $\begin{array}{c}0.52^{\star \star \star} \\
7.64\end{array}$ & $\begin{array}{l}0.39^{\star * \star} \\
7.14\end{array}$ & $\begin{array}{c}0.34^{\star \star \star} \\
7.89\end{array}$ & $\begin{array}{c}0.31^{\star \star *} \\
8.39\end{array}$ & $\begin{array}{l}0.28^{* \star *} \\
7.58\end{array}$ & $\begin{array}{c}0.36^{\star \star *} \\
3.04\end{array}$ & $\begin{array}{c}0.26^{* \star *} \\
3.86\end{array}$ & $\begin{array}{l}0.23^{\star \star \star} \\
4.60\end{array}$ & $\begin{array}{l}0.21^{\star \star \star} \\
5.14\end{array}$ & $\begin{array}{c}0.18^{\star \star \star} \\
4.82\end{array}$ \\
\hline $\begin{array}{l}\text { Port4 } \\
\text { tstat }\end{array}$ & $\begin{array}{c}1.70^{\star \star \star \star} \\
3.12\end{array}$ & $\begin{array}{c}3.47^{\star \star \star \star} \\
3.17\end{array}$ & $\begin{array}{l}5.96^{* \star *} \\
3.12\end{array}$ & $\begin{array}{c}13.44^{\star \star \star *} \\
4.89\end{array}$ & $\begin{array}{c}19.58^{\star \star \star} \\
8.36\end{array}$ & $\begin{array}{c}0.59^{\star \star \star} \\
7.84\end{array}$ & $\begin{array}{c}0.45^{\star \star \star} \\
7.74\end{array}$ & $\begin{array}{c}0.38^{* \star *} \\
7.30\end{array}$ & $\begin{array}{c}0.36^{* \star *} \\
8.50\end{array}$ & $\begin{array}{c}0.32^{\star \star \star} \\
8.96\end{array}$ & $\begin{array}{c}0.36^{\star \star *} \\
4.33\end{array}$ & $\begin{array}{l}0.29^{\star \star \star} \\
4.90\end{array}$ & $\begin{array}{c}0.23^{\star \star \star} \\
4.40\end{array}$ & $\begin{array}{l}0.23^{* \star \star} \\
5.38\end{array}$ & $\begin{array}{c}0.20^{* \star *} \\
4.91\end{array}$ \\
\hline $\begin{array}{c}\text { HiSDIPort } \\
\text { tstat }\end{array}$ & $\begin{array}{c}1.38^{\star *} \\
2.26\end{array}$ & $\begin{array}{c}2.82^{* * *} \\
3.32\end{array}$ & $\begin{array}{l}7.05^{* * *} \\
7.18\end{array}$ & $\begin{array}{c}14.03^{\star \star *} \\
12.21\end{array}$ & $\begin{array}{c}20.02^{\star \star \star *} \\
12.77\end{array}$ & $\begin{array}{c}0.74^{* \star \star} \\
7.89\end{array}$ & $\begin{array}{c}0.61^{* * *} \\
7.76\end{array}$ & $\begin{array}{c}0.56^{* \star \star} \\
9.72\end{array}$ & $\begin{array}{l}0.50^{* * *} \\
12.73\end{array}$ & $\begin{array}{l}0.44^{\star \star \star} \\
16.52\end{array}$ & $\begin{array}{c}0.53^{* * *} \\
7.08\end{array}$ & $\begin{array}{c}0.38^{* \star *} \\
6.30\end{array}$ & $\begin{array}{c}0.32^{\star \star \star \star} \\
7.42\end{array}$ & $\begin{array}{l}0.25^{* * *} \\
9.92\end{array}$ & $\begin{array}{l}0.22^{\star * \star} \\
8.68\end{array}$ \\
\hline $\begin{array}{c}\text { Hi-Low } \\
\text { tstat } \\
\text { Annualized } \\
\text { FH7 Alpha }\end{array}$ & $\begin{array}{l}0.37 \\
0.60\end{array}$ & $\begin{array}{l}1.24 \\
1.34\end{array}$ & $\begin{array}{l}3.19^{* *} \\
2.39\end{array}$ & $\begin{array}{c}5.58^{\star \star \star} \\
4.31\end{array}$ & $\begin{array}{c}5.48^{\star \star \star} \\
3.80\end{array}$ & $\begin{array}{c}0.45^{\star \star \star} \\
3.35\end{array}$ & $\begin{array}{l}0.39^{* \star *} \\
3.82\end{array}$ & $\begin{array}{c}0.34^{\star * \star} \\
4.14\end{array}$ & $\begin{array}{l}0.29^{* \star *} \\
5.77\end{array}$ & $\begin{array}{c}0.25^{* \star *} \\
7.49\end{array}$ & $\begin{array}{c}0.27^{\star \star *} \\
2.33\end{array}$ & $\begin{array}{l}0.19^{* \star \star} \\
2.58\end{array}$ & $\begin{array}{l}0.14^{\star *} \\
2.41\end{array}$ & $\begin{array}{l}0.10^{\star *} \\
2.35\end{array}$ & $\begin{array}{c}0.09^{* *} \\
2.46\end{array}$ \\
\hline Hi-Low(\%p.a.) & 1.50 & 2.50 & $3.19^{\star *}$ & $2.75^{\star \star *}$ & $1.79^{\star \star \star}$ & & & & & & & & & & \\
\hline
\end{tabular}




\section{Table 5: Panel Regression of Hedge Fund Performance on the SDI (1996Q1-2008Q4)}

Table 5 reports the panel regression results for hedge fund performance on the SDI and other fund characteristics at the quarterly frequency as the following: AbnormalPerformance $_{i, t}=c_{0 i}+c_{1 i}$ SDI $_{i, t-1}+c_{2 i}$ Control $_{i, t-1}+e_{i, t}$. Survivorship and backfill biases are controlled for to the extent data allow. Alpha is the compounded FH7-factor adjusted performance over the subsequent 1 year in percentage terms. $A R$ and $S R$ are the corresponding appraisal ratio and smoothing-adjusted Sharpe ratio. Control variables are the lagged fund characteristics including volatility of monthly net fee returns ( $\mathrm{Vol})$, lengths of redemption notice periods and lockup periods, dummy variables for personal capital commitment and high water mark, management fees, incentive fees, fund age, $A U M$, new money flow into funds within the preceding 12 months as a fraction of $A U M$, in percentage, minimum investment, and dummy for leverage usage. The $t$-statistics (reported below the estimated coefficients in italics) are adjusted for fund-clustering effect and time- and cluster style-fixed effects.

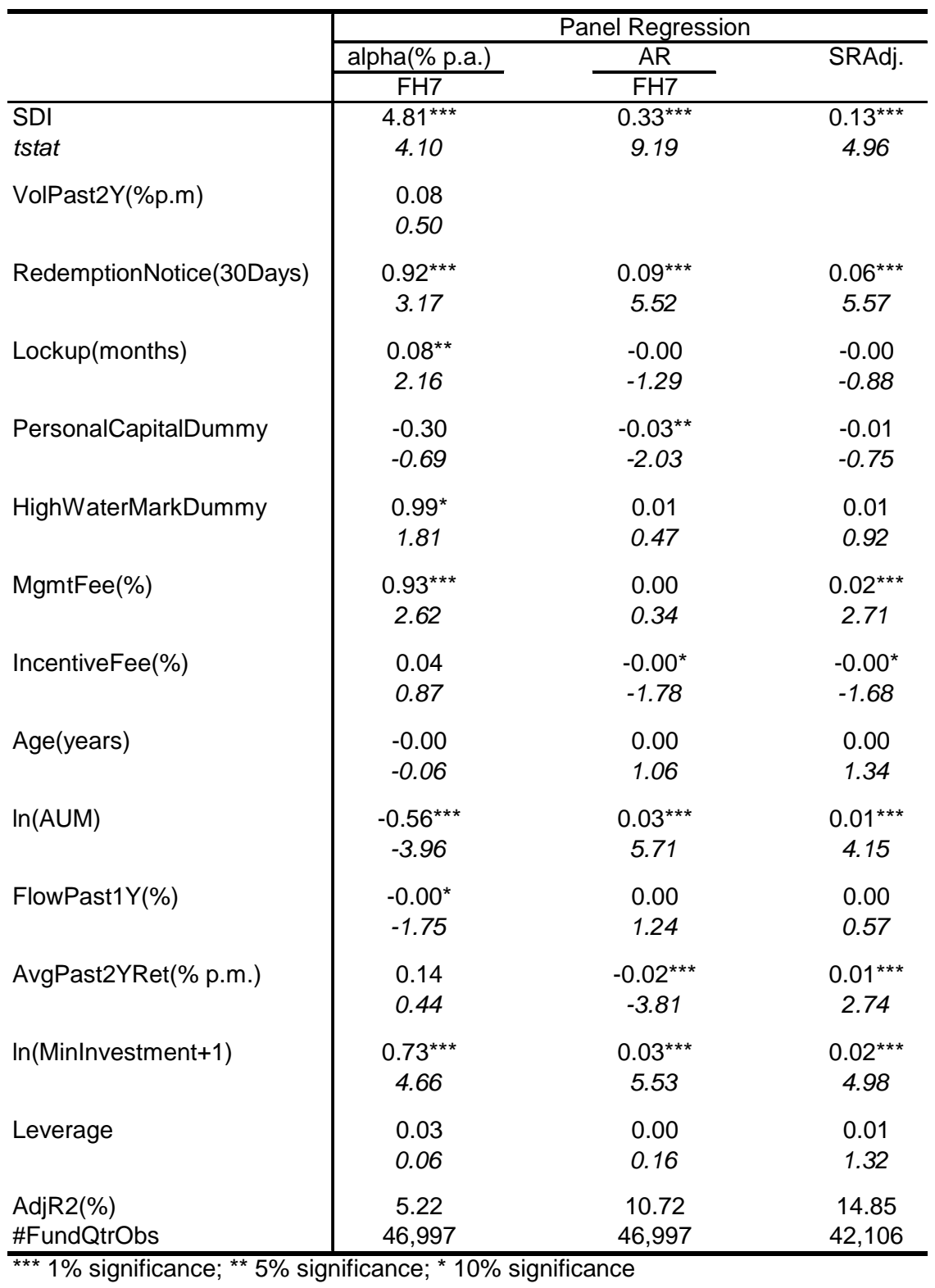




\section{Table 6: Fama-MacBeth Analysis of Hedge Fund Performance on the SDI (1996Q1- 2008Q4)}

Table 6 reports the Fama-MacBeth regression results for hedge fund performance on the SDI and other fund characteristics at the quarterly frequency as the following: AbnormalPerformance $_{i, t}=c_{0 i}+c_{1 i} S D I_{i, t-1}+c_{2 i}$ Control $_{i, t-1}+e_{i, t}$. Survivorship and backfill biases are controlled for to the extent data allow. Alpha is the compounded FH7-factor adjusted performance over the subsequent 1 year in percentage terms. $A R$ and $S R$ are the corresponding appraisal ratio and smoothing-adjusted Sharpe ratio. Control variables are the lagged fund characteristics including volatility of monthly net fee returns volatility, lengths of redemption periods and lockup periods, dummy variables for personal capital commitment and high water mark, management fees, incentive fees, fund age, $A U M$, new money flow into funds within the preceding 12 months as a fraction of $A U M$, in percentage, minimum investment, and dummy for leverage usage. Cluster-style dummies are included in the regressor set. The $t$-statistics (reported below the estimated coefficients in italicized font) are adjusted for heteroscedasticity and autocorrelation.

\begin{tabular}{|c|c|c|c|}
\hline & \multicolumn{3}{|c|}{ Fama-MacBeth Regression } \\
\hline & \multirow{2}{*}{$\frac{\text { alpha(\% p.a.) }}{\mathrm{FH} 7}$} & \multirow{2}{*}{$\begin{array}{c}\mathrm{AR} \\
\mathrm{FH} 7\end{array}$} & \multirow[t]{2}{*}{ SRAdj } \\
\hline & & & \\
\hline$\overline{\mathrm{SDI}}$ & $4.45^{\star \star \star}$ & $0.35^{\star \star \star}$ & $0.14^{\star \star \star}$ \\
\hline tstat & 2.92 & 5.11 & 3.26 \\
\hline \multirow[t]{2}{*}{ VolPast2Y(\%p.m) } & 0.03 & & \\
\hline & 0.10 & & \\
\hline \multirow[t]{2}{*}{ RedemptionNotice(30Days) } & $0.80^{\star \star \star}$ & $0.07^{\star \star \star}$ & $0.05^{\star \star \star}$ \\
\hline & 3.56 & 11.35 & 7.13 \\
\hline \multirow[t]{2}{*}{ Lockup(months) } & $0.15^{\star \star}$ & -0.00 & -0.00 \\
\hline & 2.54 & -0.88 & -0.45 \\
\hline \multirow[t]{2}{*}{ PersonalCapitalDummy } & -0.30 & $-0.03^{\star \star \star}$ & -0.02 \\
\hline & -0.61 & -2.91 & -1.40 \\
\hline \multirow[t]{2}{*}{ HighWaterMarkDummy } & 0.85 & 0.03 & 0.02 \\
\hline & 0.93 & 1.40 & 1.63 \\
\hline \multirow[t]{2}{*}{ MgmtFee(\%) } & $1.08^{\star *}$ & -0.00 & $0.02^{\star \star}$ \\
\hline & 2.36 & -0.05 & 2.47 \\
\hline \multirow[t]{2}{*}{ IncentiveFee(\%) } & 0.01 & $-0.00 *$ & $-0.00^{*}$ \\
\hline & 0.38 & -1.76 & -1.71 \\
\hline \multirow[t]{2}{*}{ Age(years) } & -0.04 & 0.00 & 0.00 \\
\hline & -0.71 & 0.06 & 0.03 \\
\hline \multirow[t]{2}{*}{$\ln (A \cup M)$} & $-0.58^{\star *}$ & $0.03^{\star \star \star}$ & $0.01^{* \star *}$ \\
\hline & -2.29 & 4.59 & 3.17 \\
\hline \multirow[t]{2}{*}{ FlowPast1Y(\%) } & -0.00 & $0.00^{\star *}$ & 0.00 \\
\hline & -1.55 & 2.55 & 1.13 \\
\hline \multirow[t]{2}{*}{ AvgPast2YRet(\% p.m.) } & 0.61 & -0.02 & $0.02^{\star *}$ \\
\hline & 0.86 & -0.98 & 2.49 \\
\hline \multirow[t]{2}{*}{ In(MinInvestment+1) } & 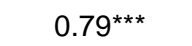 & $0.03^{\star \star \star}$ & $0.02^{* \star *}$ \\
\hline & 3.24 & 5.25 & 7.34 \\
\hline \multirow[t]{2}{*}{ Leverage } & 0.38 & -0.00 & $0.02^{*}$ \\
\hline & 0.93 & -0.17 & 1.79 \\
\hline $\operatorname{AdjR} 2(\%)$ & 18.11 & 17.70 & 14.73 \\
\hline
\end{tabular}


Table 7: Robustness: Alternative SDI Measures (1996Q1-2008Q4)

Panel A of Table 7 reports the portfolio sorting results using alternative measures of the SDI including $\left(1-\right.$ correlation) based on the TASS styles, and $\left(1-\mathrm{R}^{2}\right)$ based on TASS styles. Quintile portfolios are created by sorting on various SDIs every 3 months and held for 3 months, 6 months, and 1-3 years. The performance measures are based on the equally and value weighted buy-and-hold portfolios. Reported are the time-series means and $t$-statistics of the postformation FH7 alphas, FH7 based appraisal ratios (AR), and the smoothing-adjusted Sharpe ratios (SR) between the highest and lowest SDI portfolios. The $t$ statistics reported below in italics are adjusted for heteroscedasticity and autocorrelation.

Panel B reports the panel regression and Fama-MacBeth regression results for hedge fund performance on alternative SDIs and other fund characteristics at the quarterly frequency as the following: AbnormalPerformance $e_{i, t}=c_{0 i}+c_{1 i} S_{i, t-1}+c_{2 i}$ Control $_{i, t-1}+e_{i, t}$. Survivorship and backfill biases are controlled for to the extent data allow. Alpha is the compounded FH7-factor adjusted performance over the subsequent 1 year in percentage terms. $A R$ and $S R$ are the corresponding appraisal ratio and smoothing-adjusted Sharpe ratio. Control variables are the lagged fund characteristics including volatility of monthly net fee returns $(\mathrm{Vol})$, lengths of redemption notice periods and lockup periods, dummy variables for personal capital commitment and high water mark, management fees, incentive fees, fund age, $A U M$, new money flow into funds within the preceding 12 months as a fraction of $A U M$, in percentage, minimum investment, and dummy for leverage usage. Panel regression is adjusted for fund-clustering effect and time- and style-fixed effects, and Fama-MacBeth regression controls for style dummies and adjusts for heteroscedasticity and autocorrelation in standard errors. For brevity, only the estimation results for the SDI are reported here.

\begin{tabular}{|c|c|c|c|c|c|c|c|c|c|c|c|c|c|c|c|}
\hline \multicolumn{6}{|c|}{ Panel A: Portfolio Sorting } & \multicolumn{5}{|c|}{ AppraisalRatio } & \multicolumn{5}{|c|}{ SharpeRatio(smoothing-adjusted) } \\
\hline & $3 \mathrm{~m}$ & $6 \mathrm{~m}$ & $1 \mathrm{y}$ & $\frac{(\% \text { p.a. })}{2 y}$ & $3 y$ & $3 \mathrm{~m}$ & $6 \mathrm{~m}$ & $1 \mathrm{y}$ & $2 y$ & $3 y$ & $3 \mathrm{~m}$ & $6 \mathrm{~m}$ & $1 y$ & $2 y$ & $3 y$ \\
\hline \multicolumn{16}{|l|}{ SDI(TASS) } \\
\hline Hi-Low(EW) & $3.51^{\star \star}$ & $3.35^{\star \star}$ & $3.42^{\star \star \star}$ & $2.25^{\star \star \star}$ & $1.58^{\star \star}$ & $0.42^{\star \star \star}$ & $0.31^{\star \star \star}$ & $0.26^{\star \star \star}$ & $0.21^{\star \star \star}$ & $0.18^{\star \star}$ & $0.21^{\star \star \star}$ & $0.16^{\star \star \star}$ & $0.13^{\star \star \star}$ & $0.09^{\star \star \star}$ & $0.08^{\star \star}$ \\
\hline tstat & 2.34 & 2.02 & 2.73 & 3.69 & 2.51 & 6.08 & 6.04 & 5.57 & 12.41 & 10.54 & 3.02 & 3.21 & 3.05 & 2.58 & 2.45 \\
\hline Hi-Low(VW) & $5.51^{*}$ & $5.62^{\star \star}$ & $6.08^{\star \star \star}$ & $3.50^{\star \star \star}$ & $1.94^{\star \star}$ & $0.50^{\star \star \star}$ & $0.34^{\star \star \star}$ & $0.34^{\star \star \star}$ & $0.24^{\star \star \star}$ & $0.10^{\star \star \star}$ & $0.26^{\star \star}$ & $0.18^{\star \star}$ & $0.14^{\star \star}$ & $0.11^{*}$ & 0.10 \\
\hline tstat & 1.72 & 2.08 & 3.08 & 3.73 & 2.34 & 3.88 & 3.90 & 4.14 & 4.42 & 3.57 & 2.28 & 2.36 & 1.96 & 1.74 & 1.56 \\
\hline \multicolumn{16}{|l|}{ 1-R2(TASS) } \\
\hline Hi-Low(EW) & $4.16^{\star \star \star}$ & $4.09^{\star \star \star}$ & $4.18^{\star \star \star}$ & $4.53^{\star \star \star}$ & $5.01^{\star \star \star}$ & $0.11^{\star \star \star}$ & $0.10^{\star \star \star}$ & $0.26^{\star \star \star}$ & $0.08^{\star \star \star}$ & $0.09^{\star \star \star}$ & $0.14^{\star \star \star}$ & $0.09^{\star \star \star}$ & $0.08^{\star \star \star}$ & $0.08^{\star \star \star}$ & $0.08^{\star \star \star}$ \\
\hline tstat & 4.49 & 4.53 & 4.93 & 5.40 & 6.90 & 3.27 & 3.31 & 5.57 & 3.27 & 4.16 & 5.32 & 4.37 & 4.37 & 4.57 & 4.74 \\
\hline Hi-Low(VW) & 5.90 & $6.34^{\star}$ & $6.99^{*}$ & $7.5^{\star \star}$ & $6.33^{\star \star}$ & $0.24^{*}$ & $0.14^{\star}$ & $0.34^{\star \star \star}$ & $0.13^{\star \star}$ & $0.13^{\star \star}$ & $0.12^{\star}$ & $0.10^{* *}$ & $0.08^{\star}$ & $0.06^{*}$ & $0.06^{\star \star}$ \\
\hline tstat & 1.59 & 1.69 & 1.89 & 2.09 & 1.98 & 1.92 & 1.68 & 4.14 & 2.02 & 2.40 & 1.73 & 2.02 & 1.93 & 1.94 & 2.29 \\
\hline \multicolumn{16}{|c|}{ Panel B: Multivariate Regression } \\
\hline & & & Panel & & & & & ama-MacBe & & & & & & & \\
\hline & alpha(\% p.a.) & & AR & & SRAdj & alpha(\% p.a.) & & AR & & SRAdj & & & & & \\
\hline & $\mathrm{FH} 7$ & & FH7 & & & $\mathrm{FH} 7$ & & $\mathrm{FH} 7$ & & & & & & & \\
\hline SDI(TASS) & $3.28^{\star \star \star}$ & & $0.10^{\star \star \star}$ & & $0.03^{\star}$ & $3.94^{\star \star \star}$ & & $0.10^{\star \star \star}$ & & -0.01 & & & & & \\
\hline tstat & 4.64 & & 5.29 & & 1.88 & 2.72 & & 3.17 & & -0.20 & & & & & \\
\hline 1-R2(TASS) & $4.54^{\star \star \star}$ & & $0.14^{\star \star \star}$ & & $0.11^{\star \star \star}$ & $4.21^{\star \star \star}$ & & $0.14^{\star \star \star}$ & & 0.00 & & & & & \\
\hline tstat & 4.82 & & 6.04 & & 5.90 & 2.71 & & 3.65 & & 0.50 & & & & & \\
\hline
\end{tabular}


Table 8: Robustness: Dropout Analysis of Portfolios Sorted Based on the SDI (1996-2008)

Table 8 reports the time-series means of the survival rate, in percentage, for quintile portfolios sorted on the SDI. The portfolios are rebalanced and held for every 3-month, 6-month, and 1-3-years. It also reports the difference between the high and low portfolios, and the corresponding $t$-statistics.

\begin{tabular}{|c|c|c|c|c|c|c|c|}
\hline & LowSDIPort & Port2 & Port3 & Port4 & HiSDIPort & Hi-Low & Hi-Lo tstat \\
\hline $3 m$ & 95.94 & 95.42 & 95.16 & 95.12 & 94.60 & $-1.33^{\star \star \star}$ & -4.28 \\
\hline $6 m$ & 91.80 & 90.95 & 90.59 & 90.16 & 89.35 & $-2.45^{\star \star \star}$ & -4.67 \\
\hline $1 y$ & 83.77 & 83.09 & 81.86 & 81.18 & 79.86 & $-3.91^{\star \star *}$ & -4.35 \\
\hline $2 y$ & 69.22 & 68.82 & 67.07 & 66.22 & 64.77 & $-4.46^{\star \star \star}$ & -4.09 \\
\hline $3 y$ & 56.10 & 56.51 & 55.36 & 53.73 & 52.28 & $-3.82^{\star \star \star}$ & -2.69 \\
\hline
\end{tabular}

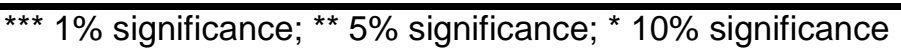

